NBER WORKING PAPER SERIES

INTERNATIONAL RESERVES BEFORE AND AFTER THE GLOBAL CRISIS:
IS THERE NO END TO HOARDING?

\author{
Joshua Aizenman \\ Yin-Wong Cheung \\ Hiro Ito \\ Working Paper 20386 \\ http://www.nber.org/papers/w20386 \\ NATIONAL BUREAU OF ECONOMIC RESEARCH \\ 1050 Massachusetts Avenue \\ Cambridge, MA 02138 \\ August 2014
}

The support of faculty research funds of the Dockson Chair, University of Southern California; the City University of Hong Kong; and Portland State University is gratefully acknowledged. We also thank Jacinta Bernadette Rico for her excellent research assistance. We are grateful to Yu-chin Chen and the participants at the April 2014 JIMF-USC conference for their insightful comments. All errors are ours. The views expressed herein are those of the authors and do not necessarily reflect the views of the National Bureau of Economic Research.

NBER working papers are circulated for discussion and comment purposes. They have not been peerreviewed or been subject to the review by the NBER Board of Directors that accompanies official NBER publications.

(C) 2014 by Joshua Aizenman, Yin-Wong Cheung, and Hiro Ito. All rights reserved. Short sections of text, not to exceed two paragraphs, may be quoted without explicit permission provided that full credit, including $\odot$ notice, is given to the source. 
International Reserves Before and After the Global Crisis: Is There No End to Hoarding?

Joshua Aizenman, Yin-Wong Cheung, and Hiro Ito

NBER Working Paper No. 20386

August 2014

JEL No. F3,F31,F32,F36

\begin{abstract}
We evaluate the impact of the global financial crisis (GFC) and recent structural changes in the patterns of hoarding international reserves (IR). We confirm that the determinants of IR hoarding evolve with developments in the global economy. During the pre-GFC period of 1999-2006, gross saving is associated with higher IR in developing and emerging markets. The negative impact of outward direct investment on IR accumulation is consistent with the recent trend of diverting international assets from the international reserve account into tangible foreign assets; the "Joneses' effect" lends support to the regional rivalry in hoarding IR as a motivation; and commodity price volatility induces precautionary buffer hoarding. During the 2007-2009 GFC period, previously significant variables become insignificant or display the opposite effect, probably reflecting the frantic market conditions driven by financial instability. Nevertheless, the propensity to import and gross saving continue to display strong and even larger positive effects on IR holding. The results from the 2010-2012 post-GFC period are dominated by factors that had been mostly overlooked in earlier decades. While the negative effect of swap agreements and the positive effect of gross saving on IR holdings are in line with our expectations, we find a change in the link between outward direct investment and IR in the pre- and post-crisis period. The macro-prudential policy tends to complement IR accumulation. Developed countries display different demand behaviors for IRs -- higher gross saving is associated with lower IR holding, possibly reflecting high-income countries' tendency to deploy their savings in the global capital markets. The presence of sovereign wealth funds motivates developed countries to hold a lower level of IR. Our predictive exercise affirms that an emerging market economy with insufficient IR holdings in 2012 tends to experience exchange rate depreciation against the U.S. dollar when many emerging markets were adjusted to the news of tapering quantitative easing (QE) in 2013.
\end{abstract}

Joshua Aizenman

Economics and SIR

USC

University Park

Los Angeles, CA 90089-0043

and NBER

aizenman@usc.edu

Yin-Wong Cheung

Department of Economics

University of California

Santa Cruz, CA 95064

and City University of Hong Kong

cheung@ucsc.edu
Hiro Ito

Portland State University

1721 SW Broadway, Suite 241

Portland, Oregon 97201

ito@pdx.edu 


\section{Introduction and Overview}

The global financial crisis (GFC) has ended the "great moderation" era, bringing instability to the fore of challenges facing policymakers in the U.S., the Eurozone, and other OECD countries - that is, volatility is back. Yet, for emerging markets, volatility never disappeared, and the GFC is another crisis in the long sequence of turbulent events, this time originating from the U.S. A key lesson of emerging markets' growing financial integration has been a greater exposure to capital flight and sudden-stop crises. ${ }^{1}$

After the financial crises of the late 1990s, many emerging markets increased their international reserves/GDP substantially, recognizing the benefits of self-insurance against the volatility associated with financial globalization. Indeed, the growing financial integration of emerging markets during the 1990s and the ensuing crises were identified as key factors in the structural changes in the motives to hold international reserves (IR), among which the weights of financial factors as well as the past crises history increased [Aizenman and Marion (2003), Aizenman and Lee (2007); Cheung and Ito (2008, 2009)]. The crises many emerging markets experienced in the late 1990s and early 2000s and the takeoff of reserves hoarding by China and other countries in the 2000s added new factors to the list of determinants of hoarding IR, including mercantilist motives [Aizenman and Lee (2008)], "keeping up with the Joneses," [Cheung and Qian (2009)], and self-insurance against local residents' flight from domestic assets in the context of the trilemma [Obstfeld, Shambaugh, and Taylor (2010); Aizenman, Chinn, and Ito (2010)].

This paper evaluates whether the GFC and recent structural changes in the global economic environment are associated with new patterns of hoarding IR. This possibility is exemplified in the recent experiences of China and South Korea, both of which have undergone large structural changes that have impacted their IR/GDP in the past decades. China became the largest IR holder in the mid-2000s, and held holds $\$ 3.8$ trillion dollars, about 33\% of the world's total, as of April 2014 (see Figure 1). After the GFC, however, China has experienced a sizable decline in IR/GDP, resulting in a rebalancing of its export-led growth strategy in the face of declining global demand, a liberalization of its outward foreign direct investment, and the placing of greater emphasis on its sovereign wealth fund (SWF) [Aizenman, Jinjarak, and Marion (2014)].

\footnotetext{
${ }^{1}$ See Calvo et al. (2004) on the empirics of sudden stops.
} 
In contrast, during the GFC, South Korea found itself struggling with confidence amid its own banking crisis. Its sizable and once regarded sufficient stock of IR failed to isolate its economy from massive deleveraging. The ensuing financial panic was ultimately abated only with the help of the Fed's offer of special swap lines. Arguably, the experience of Korea illustrated the need to supplement reserves hoarding with prudential regulations dealing with balance-sheet exposure of systemic banking. Indeed, unlike the 1997-1998 Korean crisis, the crisis this time did not lead to a further increase in Korea's reserves/GDP but to prudential regulatory changes [(Park (2010), Bruno and Shin (2014)].

The experiences of China and Korea raise the possibility that the GFC may have induced structural changes in the behavior of IR holding, possibly motivating some countries to supplement their hoarding of reserves with new policies [dynamic prudential regulations including preemptive capital controls] and institutions [financial stability boards and SWFs, among others]. These developments exemplify a growing trend among emerging markets. The GFC and the resultant quantitative easing $[\mathrm{QE}]$ policy by the Fed and other central banks also led to large, hot money inflows to emerging markets in search of yields. Emerging markets reacted to these developments by experimenting with dynamic capital controls aimed at mitigating the resultant appreciation pressure and reducing the exposure of future destabilizing outflows. These dynamic policy reactions also included relaxing controls on outward capital flows to defuse greater appreciation pressures from larger inflows, as has been the case in China and other emerging markets [Aizenman and Pasricha (2013)].

The greater reliance on sovereign wealth funds (SWF) as a means to manage the public sector's saving is another example of a possible supplement to IR hoarding, though it pre-dates the GFC. The impetus of instituting an SWF has been based on the recognition that the primary mandate of the central bank is to conduct monetary policy and ensure financial stability, not managing IR. Hence, the opportunity cost of reserves in practice may be of limited relevance for the central bank's operations. ${ }^{2}$ Therefore, once the level of IR (as a share of GDP) reaches a level high enough to cover self-insurance needs, countries, usually those with high saving rates, may opt to manage their public saving in their own SWFs. Unlike the central bank authorities, the mandate of SWFs is to secure stable income for future generations; therefore, an SWF generally has a higher risk tolerance than the central bank, and aims for higher-than-expected

2 This also explains the failure in the literature to find a stable and economically significant impact of the opportunity cost of reserves on the observed international reserves/GDP ratios. 
income and longer-term investments. Given these considerations, a higher savings rate could increase the level of IR/GDP, ${ }^{3}$ while the presence of SWFs may lower IR/GDP for a given savings rate.

Against this background, we evaluate the stability of factors accounting for IR hoarding, and the roles of conditional variables that had not been sufficiently studied before the GFC, such as the presence of SWFs, macro-prudential policies, access to bilateral swap lines, saving rates, commodity terms of trade volatility, outward foreign investment, export composition (shares of fuel, commodity, services, or manufacturing exports in total exports), gross financial exposure, and the "keeping-up-with-the-Joneses" motive.

Over time, the introduction of an SWF may reduce the exclusivity of IR as the main, or the only, financial buffer. Effective prudential regulations may reduce external borrowing and the inflows of hot money, thereby reducing the need for IR hoarding for self-insurance purposes. Accessibility to bilateral swap lines may also mitigate the need for IR at times of peril, although this applies only if the use of swap lines does not entail the stigma effect and if the swap-line arrangements are deemed durable. Export composition and terms of trade volatility matters in determining the volatility of trade and the real exchange rate, explaining patterns of pro-active, leaning-against-the-wind type of exchange rate and reserves policies.

Previewing results, we group the explanatory variables into three broad factors. The traditional macroeconomic factors include the propensity to import, the volatility of IR holdings, the opportunity cost of holding IR, and exchange-rate regimes. These variables capture the elements of an international reserve- demand equation from vintage 1970s. The financial factors include domestic financial depth (measured by M2/GDP), external financing, cross-border capital flows, and capital controls on capital flows. The third group includes several factors that have come to the fore in recent discussions: the existence of national-level SWFs, bilateral currency-swap agreements, the implementation of macro-prudential policies, gross saving, outward direct investment, the composition of trade, the implicit-rivalry incentive (also known as the "catching-up-with-the-Joneses' effect"), and the discounted experience of past financial crises.

We confirm that the appropriate level of IR is not necessarily constant and determining

3 Political economy considerations suggest another channel linking a lower gross savings rate with lower IR/GDP; such a scarcity of saving would make it harder for the central bank to maintain sizable hoarding of IR, as the reserve stock may be an administration's target of opportunity at times of a fiscal crunch, as has been the experience of Argentina and Venezuela [Aizenman and Marion (2004)]. 
factors continue to evolve with developments in the global economy. In 1999-2006, the pre-GFC period, gross saving is associated with higher international reserves in the developing and emerging markets; the outward direct-investment effect is consistent with the efforts of diverting international assets from the IR account into the purchase of more tangible foreign assets; the Joneses' effect lends support to the implicit rivalry-hoarding motives; and commodity-price volatility induces IR hoarding against uncertainty while fuel exporters store their proceeds partly in the form of foreign reserves. During the 2007-2009 GFC period, many of the variables that are significant contributors to IR hoarding in the previous period become insignificant or display the opposite effect, probably reflecting the frantic market conditions that prevented a normal economic relationship to hold. Nevertheless, the propensity to import and gross saving continue to display strong positive effects (with greater magnitudes). The results for the post-GFC 20102012 period are dominated by the "recently discussed factors." While the negative effect of swap agreements and the positive effect of gross saving on the observed IR/GDP are in line with our expectations, the positive outward direct-investment effect implies a change in the link between outward direct investment and IR holding behavior in the pre- and post-crisis periods. Such a change deserves further analysis in future studies. The SWF seems to exert positive effect on IR accumulation. Some other findings are unexpected or not totally intuitive such as a negative Joneses' effect among developing countries in Europe and the effect of banking-crisis experience. Interestingly, most of these non-intuitive results disappear - they become either insignificant or significant with the expected sign - when we pool the data from all the three subsample periods. In addition, in the entire sample period, the existence of macro-prudential policies is found to complement the IR-accumulation policy.

We repeat the exercise using data from developed countries. In line with previous findings in the literature, the developed and developing countries display fairly different IR demand behaviors. We find that the IR hoarding behavior of developed countries is affected by the recently discussed factors, including SWFs, gross saving, the Joneses effect, and trade compositions, even in the pre-GFC period, though their results often differ from those of developing countries. For example, the presence of an SWF has different implications for the levels of IR holding of developed and developing countries in the pre-GFC years. Also, gross saving has a negative impact on IR accumulation of developed countries, possibly because these countries have better accessibility to the global capital market where they can invest their savings. 
The Joneses effect is quite robust among both developed and developing Asian countries.

Overall, the lists of significant variables are quite different between the groups of developed and developing countries. At the minimum, the statistical-demand specification for IR holdings not only evolves over time, but also differ between developed and developing countries. All these suggest that the two groups of countries have different motivations for holding IR because they face different economic realities.

We close with an examination of the adequacy of IR holdings in the 2010-2012 period as was reflected in exchange market pressures. Our empirical analysis confirms that the "fragile five" countries (Brazil, India, Indonesia, South Africa, and Turkey) held fewer IR than our model predicted in this period. Such a situation reflects the vulnerability of these countries to global economic turbulences in the early 2010s. We test whether and to what degree economies with IR-holding levels below model predictions are susceptible to external shocks, focusing on the induced exchange rate depreciation against the U.S. dollar between 2012 and 2013, a period dominated by the news coming from the Fed that QE may be tapering soon. We confirm a negative and significant correlation between the exchange rate depreciation against the U.S. dollar and our proxy for over-hoarding of IR given by the prediction error of IR holdings. That is, if a country held an insufficient amount of IR, it tended to experience depreciation in its currency value when adjusting to the tapering news.

Sections 2 and 3 outline the empirical specifications and report the estimation results. Section 4 compares the observed levels of IR hoarding with model predictions for several emerging markets, and examines the link between prediction errors in IR hoarding and exchange rate depreciation in 2012-2013. In Section 5, we reexamine the determinants of IR holding using different estimation techniques as robustness checks. Section 6 provides concluding remarks.

\section{Empirical Specifications}

Our analysis examines annual data of 95 countries, 22 developed countries and 73 developing countries, from 1999 to 2012. Given the existing evidence that the IR demand behavior differs across different historical time periods partitioned by global events and between advanced and developing economies, we implement our empirical exercise for a) advanced and 
developing economies separately, and for b) three disjointed sample periods; namely 1999-2006, 2007-2009, 2010-2012.

\section{$2.1 \quad$ Models}

We use the following regression equations to study the IR demand behavior:

$$
\begin{aligned}
& r_{i, t}=c+X_{i, t-1}^{\prime} \alpha+Y_{i, t-1}^{\prime} \beta+D_{i}^{\prime} \delta+\varepsilon_{i, t}, \text { and } \\
& r_{i, t}=c+X_{i, t-1}^{\prime} \alpha+Y_{i, t-1}^{\prime} \beta+D_{i}^{\prime} \delta+Z_{i, t-1}^{\prime} \gamma+\varepsilon_{i, t} .
\end{aligned}
$$

The variable of interest is $r_{i, t}=R_{i, t} / G D P_{i, t}$, where $R_{i, t}$ and $G D P_{i, t}$ are, respectively, generic notations of economy $i$ 's holding of IR and gross domestic product (GDP) at time $t$ with both variables measured in U.S. dollars. Scaling IR as a ratio to GDP facilitates comparison across countries of different sizes. For brevity, we call the ratio $r_{i, t}$ international reserves (IR), henceforth.

The four types of determinants are: a) $X_{i, t}\left(=\left\{x_{i, k, t} ; k=1, \ldots, N_{x}\right\}\right)$ includes the traditional macro variables, b) $Y_{i, t}\left(=\left\{y_{i, k, t} ; k=1, \ldots, N_{y}\right\}\right)$ includes the financial variables, c) $D_{i, t} \quad(=$ $\left.\left\{d_{i, k, t} ; k=1, \ldots, N_{d}\right\}\right)$ includes other characteristics of the economies, and d) $Z_{i, t}$ (= $\left.\left\{z_{i, k, t} ; k=1, \ldots, N_{z}\right\}\right)$ includes the possible determinants discussed during the GFC and afterwards. The definitions of these variables and their sources are given in Appendix 1. The coefficient vectors $\alpha, \beta, \gamma$, and $\delta$ are conformable to the associated explanatory variables. The intercept and disturbance term are given by $c$ and $\varepsilon_{i, t}$, respectively.

With (1) as a benchmark, the relevance of the determining factors that come to the fore during and after the GFC could be gauged by comparing results from (2) with those from (1).

\subsection{Explanatory Variables}

The traditional macroeconomic variables considered under $X_{i t}$ are motivated by existent studies on IR holding behavior, including Frenkel (1974a, b), Frenkel and Jovanovic (1981), Heller (1966), and Kelly (1970). These variables include the propensity to import, the volatility of IR holding, and the opportunity cost of holding IR. Thus, the $X_{i t}$ component of (1) captures the elements of an IR demand equation of the 1970s vintage.

\footnotetext{
$4 \quad$ Our sample period starts in 1999 based on the findings in Cheung and Ito (2008, 2009). They find that economies alter their IR holding behaviors before and after major global financial disturbances, and that the last global break point for IR holding is the Asian financial crisis of 1997-1998. They also find that the developed and developing countries displayed different IR hoarding behaviors; see also Bahmani-Oskooee (1988), Bussière, et al. (2014), Frenkel (1974a), Frenkel (1980), and Lizondo \& Mathieson (1987).
} 
The main economic characteristic $\left(D_{i t}\right)$ discussed in the subsequent literature is the exchange rate regime arrangement. Frenkel (1980) and Flood and Marion (2002), for example, report that exchange rate arrangements have effects on the holding of IR, while Lane and Burke (2001) find no significant effect. Other country-specific characteristics including the past crisis experiences are considered under $Z_{i t}$.

Financial factors are playing an increasingly important role in the global economy in general, and influencing the behavior of IR holding in particular (Aizenman and Lee 2007). The financial variables in $Y_{i t}$ include domestic financial depth (measured by M2/GDP) and external financing capacity measured by net portfolio investment position. The money stock in a developing economy is considered as a proxy for the potential magnitude of capital flight. Holding IR can act as a buffer against such "internal drain" and alleviate the adverse impact of sudden capital flight. ${ }^{5}$

There are different views on the implications of external financing for IR holdings. One view is that economies with a large external financing exposure in the forms of debts or portfolio flows hold a high level of IR to guide against the possibility of reverse capital flow (Aizenman et al., 2007; Feldstein, 1999). ${ }^{6}$ However, if external financing is a substitute for foreign reserves, then the correlation between the two variables will be negative.

The variations in IR holdings observed during and after the GFC have led to further discussions on the determination of the appropriate amount of IR. The variable $Z_{i t}$ includes determining factors that received more attention among researchers in the recent discussions.

Countries may institute sovereign wealth funds (SWFs) to hold and manage their external assets. Typically, the monetary authorities use their IR to fund an SWF, suggesting that the existence of an SWF can be negatively correlated with the level of IR holding. However, the possibility of shifting external assets to an SWF offers a way to divert political pressures on excessive IR holding. If it is the case, then IR holding could even increase in the presence of a SWF. To assess its role, we include the dummy variable that represents the presence of national-level SWFs in our empirical analysis. ${ }^{7}$ In passing, we note that the use of the SWF

\footnotetext{
5 See, for example, de Beaufort Wijnholds and Kapteyn (2001), Calvo (1998, 2006), Aizenman and Lee (2007), and Obstfeld, et al. (2009)

6 Dooley et al. $(2005,2009)$, based on the Bretton Woods II system argument, note that external financing flows and levels of IR hoarding are positively related.

7 The information is from the SWF Institute (http://www.swfinstitute.org/fund-rankings/). Canadian or American SWFs are not included in the analysis because they are all managed by provincial or state level authorities,
} 
tenure does not change the results reported below.

Bilateral currency swap agreements are another factor. If a country has access to hard currencies via a currency swap arrangement, then it may have a weak incentive to hold IR. We collect the from official websites information on bilateral swap agreements (regardless of the currency of the agreement) signed since the breakout of the 2008 global financial crisis.

The desire or the need to hold IR could be affected by the implementation of macro prudential policies, which have attracted considerable discussions in the global community in the aftermath of the GFC (Ostry et al., 2010; Ostry et al., 2011; The Strategy, Policy, and Review Department, IMF, 2011). We include a qualitative variable that assumes a value of one if a country implemented any of the macro prudential policies based on the information in Lim, et al. $(2012,2013)$.

Countries with a high level of gross saving tend to run a current account surplus, and accumulate IR, unless they are purposefully investing the surplus abroad. Thus, a country's saving could be indicative of the level of IR holding. By the same token, a policy of promoting outward direct investment (ODI) is one means to deploy international assets overseas. Hence, the level of ODI can be negatively correlated with the level of IR holding. In the subsequent empirical analyses, both gross saving and ODI are expressed as a ratio to GDP.

Besides the usual economic considerations, the implicit rivalry incentive could drive countries to accumulate IR in a "competitive" manner. Machlup (1966) first noted the so-called "catching-up-with-the-Joneses effect," and the Joneses effect was revived by Cheung and Qian (2009) and Cheung and Sengupta (2011). Given the regional characteristics of the Joneses effect, we allow for countries in different regions to display different Joneses effects by interacting the Joneses variables with the corresponding regional dummy variables. ${ }^{8}$

The composition of trade, in addition to trade intensity, can affect the IR hoarding behavior. Hence, we explore the possible effects of the shares of fuel, commodity, or manufacturing exports in total exports, commodity terms of trade volatility, and the relative share of goods to services exports.

We also control for the potential effects of past experiences of currency and/or banking crises. For each type of crisis, we use a dummy variable for the crisis experience in the preceding

and are thereby not supposed to affect the holding of international reserves at the country level.

8 The regions are: "North and South America," "Europe," which includes Western, Central, and Eastern Europe, "East and South Asia," "Middle-east and North Africa," and "Sub-Saharan Africa." 
five-years (that is, $\mathrm{t}-1$ to $\mathrm{t}-5$ ), and calculate $\mathrm{D}_{\mathrm{c}(t-1)}+.95 * D_{c(t-2)}+.90 * D_{c(t-3)}+.85 * D_{c(t-4)}$ $+.80 * D_{c(t-5)}$, where $\mathrm{D}_{\mathrm{c}(.)}=1$ if there is a crisis, and $=0$, otherwise. In essence, we assume that the memory of a crisis among policy makers "depreciates" at the annual rate of $5 \%$.

Most of these data are extracted from the World Development Indicator, International Financial Statistics, and the IMF's World Economy Outlook. See Appendix 1 for detail.

\section{Estimation Results}

Our discussion is focused on the estimation results of developing countries. The results of developed countries are included mainly for comparison purposes.

\subsection{Basic Results - Developing Countries}

Table 1 summarizes the results of estimating equation (1); that is, the estimation without the newly focused variables $\left(Z_{i t}\right)$, for the subsample of developing countries. We estimate the model with country-fixed effects because the Hausman test chooses a fixed effects specification over a random effects specification. To avoid the endogeneity issue, all the right-hand-side variables are lagged by one year. We choose the model specification in Table 1 using the following strategy. First, in the pre-test stage, we consider the 1999-2006 period, and examine all the possible traditional macroeconomic, financial, and (institutional) characteristics variables; that is, $X_{i t}, Y_{i t}$, and $D_{i t}$. We sequentially drop insignificant variables, and come up with the specification reported in column 2 of the table. Then, we fit the same model to the sample periods of 2007-09, 2010-12, and 1999-2006.

A few observations are in order. First, in the 1999-2006 subsample, the positive effect of the propensity to import variable suggests that a higher level of IR is expected to cover a higher level of imports (Frenkel, 1974b). The negative reserve volatility effect, however, is different from the prediction of the buffer stock model of IR (Frenkel and Jovanovic, 1981). In the current panel setting, the negative effect could be associated with the anecdotal observation that large variations in a developing country's IR are usually caused by large drawn downs.

In addition to the internal drain and capital flight interpretation, the positive money supply stock effect is also in line with the early monetarist model of balance of payments that predicts an excess demand for money leads to an increase in IR (Courchene and Youssef, 1967; Johnson, 1958). The other financial variable, the net value of portfolio liabilities, on the other hand, has a significantly negative effect on IR holdings. One possible interpretation is that, on average, developing countries treat IR and portfolio flows as substitutes. 
Second, the performance of these explanatory variables in the tranquil 1999-2006 period is quite different from their performance during the GFC crisis and post-crisis sample periods. The coefficient estimates of these variables change in terms of the magnitude, the sign, and the level of significance. For instance, during the 2007-2009 crisis period, the propensity to import is the only significant variable. During the post-crisis period, the import propensity effect becomes negative - a finding that is counter-intuitive. ${ }^{9}$ When we pool the three sample periods, the estimation results resemble those of the pre-GFC 1999-2006 period, with the exception that the net portfolio liabilities show no significant effect.

These results reinforce the previous findings that the IR demand function as well as its determinants are evolving over time (Cheung and Ito, 2008, 2009). Apparently, authorities respond to market conditions and adjust their reserve hoarding behavior accordingly. That is, the level of IR that is deemed sufficient is not necessarily constant.

\subsection{The "New" Factors - Developing Countries}

Here, we examine the results pertaining to the variables in $Z_{i t}$; that is, determining factors which have received considerable attention during the GFC and in its aftermath.

We augment the first estimation model shown in Table 1 with the elements of $Z_{i t}$ along with the variables from $X, Y$, and $D$ that were found significant. As we did previously, we started with all the variables (shown in Appendix 1) and sequentially dropped insignificant variables until we obtained a parsimonious representation comprised only significant explanatory variables. We repeated the exercise for each of the sample periods, and reported the results in Table 2 for developing countries and Table 3 for developed countries.

One obvious observation is that the "newly discussed" variables $\left(Z_{i t}\right)$ have different effects over different sample periods. ${ }^{10}$ Although these variables are labeled as "recently discussed" factors, some of these variables are statistically significant even in the pre-GFC period. For example, gross saving has the expected positive sign in all the sample periods. This result lends support to the view that, for developing countries, a high level of national saving leads to a better current account balance and a higher level of IR holding. ${ }^{11}$

9 The negative effect of the propensity to import is consistent with Heller's (1966) argument that the demand for IR should be negatively related to the marginal propensity to import because a higher propensity to import $(\mathrm{m})$ implies a smaller marginal cost of balance of payments adjustment (that is, $1 / \mathrm{m}$ ).

10 Indeed, the Chow tests confirm that the estimation models from different subsample periods are significantly different from each other; that is, there are structural changes in the set of explanatory variables over time. These results are available upon request.

11 That implies that financial account is relatively closed compared to current account, which is often the case 
The outward direct investment effect in the pre-GFC years is consistent with the view that investing overseas helps divert international assets from IR accumulation. As anticipated, the Joneses effect varies across different regions and over different time periods. The Joneses effects for Asian countries in the pre-GFC and full sample periods echo the results reported in Cheung and Qian (2009). However, the region's rivalry-driven IR hoarding motive reverses its sign during the crisis period. Countries in other regions do not display a stable Joneses effect across the sample periods, either.

The two commodity-related variables, the manufactured exports ratio, and the two crisis variables do not perform consistently across the sample periods, though fuel exports seem to be a positive factor especially in the pre-GFC period. The negative banking crisis effect is somewhat difficult to interpret, but it may suggest that a country that experienced a banking crisis in the past tends to experience persistent external drain.

During the 2007-9 crisis period, some of the variables found significant in the pre-crisis period become insignificant, some insignificant variables become significant, while some continue to be significant but display the opposite effect. The change in the performance of these variables may not be surprising because the crisis-driven frantic market conditions could prevent normal economic relationships from holding. Nevertheless, the propensity to import and gross saving continue to display a strong positive effect even with greater magnitudes.

The result from the post-crisis 2010-2012 period may be the most surprising one. The list of significant variables is dominated by the factors included in $Z_{i t}$. Interestingly, signing on a bilateral currency swap agreement with a major central bank negatively contributes to IR accumulation, suggesting that currency swap agreements can supplement IR accumulation. ${ }^{12}$ Given the negative effect of swap agreements is found in the immediate aftermath of the GFC, we conjecture that the negative effect is not driven by stigma (or possibly resultant speculative attacks) from signing on the agreements. Rather, we can stipulate that a swap agreement can relax liquidity constraint and ensure accessibility to a hard currency when there is liquidity shortage. The access to hard currencies is especially helpful when the global economic

for many developing countries including China.

12 We include a dummy variable that takes the value of one if a country has a bilateral currency swap agreement with a major central bank (regardless of the currency of the agreement) such as the Fed, the ECB, and the Bank of Japan. This dummy variable does not refer to the currency swap agreements with the People's Bank of China because the Chinese renminbi is not capital account convertible and, thus, does not provide liquidity to the same extent as major hard currencies do. 
conditions are still fragile in the immediate aftermath of the GFC. Hence, a swap agreement provision allows countries to hold less of IR than they would otherwise.

We continue to find the positive effect of gross saving in the post-crisis period, signifying the important role of saving. The positive outward direct investment effect, however, implies a change in the link between outward direct investment and IR hoarding in the pre- and post-crisis periods. Such a change deserves further analysis in future studies.

As far as the post-GFC years are concerned, having an SWF seems to have a positive externality on IR accumulation. However, the estimate is found to be significantly negative in the full sample period, which is more in line with our priors, making the positive externality only unique to the post-GFC period.

Interestingly, when we pool the data from the three sample periods, most of the non-intuitive results in the crisis- and immediate post-crisis periods disappear (either become insignificant or significant with the expected sign). In addition, the macro prudential policy is found to complement the IR accumulation policy while having an SWF could divert international assets from IR accumulation. ${ }^{13}$

\subsection{The Developed Countries}

We repeat the same exercise for the sample of developed countries and present the results in Table 3. In accordance with the past literature, developed and developing countries display different IR demand behaviors in each of the sample periods.

For developed countries, some of the "recently discussed" factors, such as SWFs, gross saving, the Joneses effect, and trade compositions affect the reserve hoarding behavior, even in the pre-GFC period. However, the estimated effects reported in Table 3 are different from those of developing countries in Table 2. For example, the presence of an SWF decreases the level of IR holding in the pre-GFC years, and gross saving has a negative impact on IR accumulation. The different saving effect may be caused by the fact that developed countries have better accessibility to the global capital market where they can invest their savings. The Joneses effect is quite robust among the Asian countries, a common characteristic between developed and developing countries.

Overall, the lists of significant variables in Tables 2 and 3 are quite different. Besides

13 We also investigated the effect of IMF stabilization measures by including a country-specific dummy variable that takes the value of one if a country receives non-concessional loans from the IMF in year $t$. However, this dummy variable is not statistically significant in any of the models considered. 
gross saving, the contrasting results of the opportunity cost and M2 variables are noteworthy; among developed countries, both variables have negative impacts on IR accumulation. In a country with more developed financial markets, that can be suggested by a higher level of M2 (as a share of GDP), holding a large amount of IR can involve higher levels of foregone investment opportunities. This also explains why the estimate on the opportunity cost is significantly negative in all the sample periods except for the pre-GFC period, a result consistent with theoretical predictions and in contrast with the case of developing countries in the 2007-09 crisis period. Other variables with conflicting results compared to developing countries include bilateral swap agreements and banking crisis experience.

\section{Prediction Exercises}

\subsection{Are Developing Countries Over- or Under-Hoarding International Reserves?}

In the last two decades or so, economists and policymakers alike have been debating on the issue of the adequacy of IR holding. While holding an insufficient level of IR can trigger economic and financial instabilities, excessive hoarding of reserves can lead to over-heating of the domestic economy and contribute to global economy instability. An overarching issue of the debate is how to determine the 'sufficient' level of IR, either theoretically or empirically. While the debate on what level of IR constitutes a 'sufficient' level cannot be settled, at the very least, we can provide a statistical benchmark based on the past historical patterns of IR holding so as to obtain some inferences about whether the actual level of IR holding is too high or too low.

The estimation results in the previous section clearly show that the empirical IR demand function has evolved over time, including different sets of factors as the determinants in different time periods. Thus, even if we wanted to estimate a benchmark level of IR as a reference point, the estimated degree of over- or under-hoarding would depend upon which empirical model to compute the benchmark. Nonetheless, we use our estimated models to generate the predicted levels of IR and compare them with the actual levels of IR hoarding.

Figure 2 plots predicted levels of IR holdings for selected individual countries and countries groups based on the estimated models reported in Table 2 for different sample periods and, the corresponding actual levels. . The individual countries include Argentina, China, Korea, Malaysia, Mexico, Thailand, and the "Fragile Five" of Brazil, India, Indonesia, South Africa, and Turkey. The country groups are the developing Asia excluding China, Latin America, and 
emerging market economies. ${ }^{14}$ For each specification, we generate the in-sample and out-of-sample forward, but not backward, predictions. For example, by using the model estimated for the 2007-2009 sample, we generate in-sample predictions for 2007 to 2009, and out-of-sample predictions for 2010 to 2012.

Regarding these graphs, we must note that the predictions are generated without country-fixed effects, though the estimations are conducted with country-fix effects. We conceive that predictions made without country-fixed effects would resemble the way international investors compare cross-country investment destinations for arbitrage opportunities. One could argue that predictions with country-fixed effects are relevant only for assessing whether the path of actual holdings of IR are higher or lower relative to their historical tendencies. However, international investors would also compare the levels of IR holding across countries so that they could react to market signals and reorganize their portfolios when necessary.

Let us consider the period of 2010 to 2012. In the figure, we can see that, among the predictions of the demand for IR estimated for the four sample periods, the predictions for the 1999-2006 and 1999-2012 periods tend to resemble each other, reflecting the estimation results in Table 2. For some individual countries or country groups, predictions from the 2007-2009 or 2010-2012 specifications differ greatly from those of either 1999-2006 or 1999-2012 specifications.

These plots confirm that whether a country is under- or over-hoarding IR depends on which estimation model to use to compute the benchmark. For example, during the 2010-2012 period, China appears to hold IR far more than those predicted by the model estimated for the 2007-2009 period, but less than what is predicted by the other three specifications, especially the 1999-2006 model. Figure 2 shows similar results for other Asian economies and the group of ex-China Asian developing economies. In short, Figure 2 suggests that many of the countries displayed in the figure appear to "under-hoard" IR according to the benchmarks based on either 1999-2006 or 1999-2012 specifications. These results suggest that the behavior of IR holding for these countries may have experienced a regime shift after the GFC.

Table 4 allows us to take a closer look at the IR holding behavior in reference to the different benchmarks by reporting the averages of prediction errors in 2010-2012 for the same countries as in Figure 2 and the country groups of "Emerging Asia," "Western Europe," Eastern 
and Central Europe," "Emerging Latin America," "Fragile Five," and "BRICS."15 The first four columns report the 2010-2012 averages of prediction errors while the errors do not incorporate country-fixed effects. The second four columns report the 2010-2012 averages of prediction errors, but the errors do reflect country-fixed effects. ${ }^{16}$ As we have discussed previously, the errors without country-fixed effects are more suitable for cross-country comparison, but those with country-fixed effects are suggestive of over- or under-hoarding from historical perspectives for each country.

The country group averages of prediction errors without country-fixed effects suggest that the country groups of Emerging Asia, Fragile Five, and BRICS appear to hold fewer IR than the predictions using either the 1999-2006 or 1999-2012 model, implying that these country groups may have experienced a significant change in the behavior of IR holding after the GFC. The result is somewhat surprising in view of the anecdotal argument that massive IR allowed emerging Asian economies to be resilient to the GFC. However, the result for this group is mainly driven by the results of India, Indonesia, and Korea. ${ }^{17}$ Figure 3, which compares the actual and predicted levels of IR holding for the 1999-2006 and 1999-2012 models, confirms the result graphically.

However, the prediction errors that incorporate country-fixed effects give us a more nuanced picture. The 'under-hoarding' countries based on the 1999-2006 or 1999-2012 models are now reduced to India, Indonesia, Korea, and Malaysia. Countries like China and Thailand are not 'under-hoarding' compared to their historical patterns. Among the country groups, according to the 1999-2006, only the Fragile Five appears to be under-hoarding compared to its pre-GFC patterns.

Figure 2 confirms the under-hoarding of IR by "Fragile Five," that could be viewed by the market as vulnerable to the reverse of the U.S. quantitative easing (QE) policy. These five countries tend to be deficient in IR holding during the period of 2010-2012; they usually appear to be under-hoarding by three of the four specifications. Combined with the results in Table 3 and Figure 3, among the Fragile Five, India and Indonesia particularly appear vulnerable, justifying the market's concern over these economies' deteriorating current account conditions.

\footnotetext{
15 "BRICS" comprises Brazil, Russia, India, China, and South Africa. The in-sample country fixed effects are used in the process of calculating these errors.

Sri Lanka and Pakistan, both included in the Emerging Asia group, also displayed IR under-hoarding based on the 1999-2006 and 1999-2012 specifications.
} 


\subsection{International Reserve Holdings and Currency Depreciation}

How are the countries vulnerable to external financial shocks doing lately? In recent years, emerging market economies have ambivalent feelings about the spillovers from advanced economies. On the one hand, emerging market economies should benefit from the recovery of advanced economies, which are their important trading partners after all. On the other hand, with recovery underway, the advanced world will trigger the tapering policy to end the extremely low interest rate policy, which could in turn cause massive capital outflow from emerging market economies. Indeed, on May 22, 2013 the world witnessed the adverse effect of tapering on emerging financial markets when the comment by the Federal Reserve chairman Ben S. Bernanke on the possibility of tapering the QE policy ended up jittering the emerging economies.

As amplified in the media, economies that are financially vulnerable, including the Fragile Five discussed above, have been experiencing economic and financial stresses. One sign of economic and financial stresses is exemplified by the falling value of the domestic currency which is caused by concerns over anticipated capital outflow and possible deteriorating economic performance.

Although our estimation results do not answer definitely the question of whether or to what extent a country is holding too much or too little IR, they can shed light on the relative sufficiency or deficiency of IR hoarding. To investigate the issue, we study the possible links between our estimates of IR holding and the observed exchange rate movements. Specifically, we investigate whether the currency stress is associated with the relative levels of IR holding to our predictions, which we interpret as a barometer of a country's vulnerability to external financial shocks.

Figure 4 displays scatter diagrams of the magnitude of the U.S. dollar exchange rate depreciation against the degree of over-hoarding of IR, which is measured by the prediction error based on our estimated models. The prediction errors, or the proxies for "over-hoarding," are defined as the difference between the actual and predicted levels of IR - a positive difference implies over-hoarding and a negative one under-hoarding. If a prediction error is a reasonable measure of vulnerability to external financial shocks, a fall in the prediction error should be associated with a rise in the exchange rate (that is, currency depreciation).

The scatter plots of the annual averages of exchange rate depreciation observed during the year of 2013 and the over-hoarding proxies for the period of 2010-2012 display different 
patterns depending on the estimation model to use. For instance, the proxies derived from the 2010-2012 model (Panel C) exhibit a wide dispersion relative to those from other model specifications. Nonetheless, a (weak) negative association of the two variables could be visualized in these four scatter plots.

To shed additional insight, we regress the rate of depreciation of the exchange rate against the U.S. dollar on the proxy for IR over-hoarding, and report the results in Table 5. Two types of over-hoarding proxies are considered: one is the average of the 2010 to 2012 values, and the other is the proxy value as of 2012 .

The estimation results lend support to the visual inspection that the two variables are negatively related. When we use the proxy average of the 2010 to 2012 period, all coefficient estimates are negative and, with the exception of the 2010-2012 case, statistically significant. The explanatory power, as given by the adjusted R-squared estimates, ranges from $0 \%$ to $6 \%$ for the significant cases. Apparently, the information conveyed by the 2012 proxy for over-hoarding has a stronger impact for exchange rate depreciation than the one embedded in the annual averages of 2010 to 2012. Generally, the adjusted R-squared estimates are higher as well.

Based on the presumption that the market will drive down the currency value of a country experiencing signs of external vulnerability and a resultant fall in IR holding, our findings either lend support to this presumption or are indicative of the relevance of the estimated demand models for international reserves (with the 2010-2012 model as a likely exception). A strong inference is that, if a country holds a deficient amount of international reserves, it tends to experience currency depreciation. Furthermore, the outcome will be reinforced by foreign exchange market interventions conducted by countries' monetary authorities that would further deplete the holding of reserves.

\section{Additional Analyses}

\subsection{A Robustness Check with the Principal Component Analysis (PCA)}

Admittedly, we considered a large number of potential explanatory variables to investigate the reserve holding behavior. The regression analysis may suffer from the issues associated with the curse of dimensionality. Although the correlation between the reported explanatory variables is usually not strong, some members of the original set of potential explanatory variables overlap with others conceptually or qualitatively (for example, the share of 
fuel in total exports and that of commodity exports), and thus can display a high level of association with each other. Hence, it is worthwhile assessing the robustness of the estimation results by controlling for potential multicollinearity.

To reduce the dimensionality, we consider principal components (PCs) of individual groups of potential explanatory variables instead of the variables themselves in the regression analysis. Principal component analysis (PCA) is a statistical tool that extracts PCs, which are orthogonal linear combinations of a set of variables based on their ability to capture the variations of these variables. While each of the PCs is correlated with some of the original variables, PCs are orthogonal to each other. Applying PCA to $p$ number of variables would yield $p$ number of PCs. However, usually, using some threshold (e.g., the Kaiser criterion), only a fewer number of PCs than $p$ could be chosen because they are sufficient enough to cover most of the variation of all the original variables. In short, PCA has the benefit of reducing the dimension of the parameter space with a minimum loss of information. See Appendix 2 and Anderson (2003) for additional discussions of PCA.

To have a better understanding of how to apply this methodology in our context, let us think about the following hypothetical case. Assume that the level of IR hoarding (as a share of GDP: $\left.r_{i, t}\right)$ is estimated as a function of $\left\{x_{1(-)}, x_{2(+)}, x_{3(-)}, x_{4(+)}, x_{5(+)}\right\}$ with the estimated signs shown in parentheses. When we apply PCA to $x$ 's, it turns out that we get the first and second PCs (PC1 and PC2) as the PCs that sufficiently covers the variations of the original $x$ 's. We also find PC1 highly positively correlated with $x_{2}$ and $x_{4}$ and PC2 negatively with $x_{1}$ and $x_{3}$. If we regress $r_{i, t}$ on $P C 1$ and $P C 2$, as long as the estimates on both $P C 1$ and $P C 2$ are positive, we could conclude that such a finding is consistent with the original estimation, because the signs are consistent.

Using the PCA, we extracted the PCs of the group of macroeconomic/financial variables and the group of trade/industrial structure and obtain PCs. ${ }^{18}$ Table A1 in Appendix 2 reports the

18 See Appendix 2 for selection criteria. We combined the macro/traditional variable group $\left(X_{i t}\right)$ and the financial variable group $\left(Y_{i t}\right)$ into one variable group and extracted thier PCs. Also, as Appendix 2 shows, we included some of the "recently discussed" variables in $Z_{i t}$, such as gross saving, outward direct investment, and the crisis variables, in this group as well because it is reasonable to expect these variables are correlated with each other. By extracting PCs from a large number of variables, we obtain large variable reduction effects. We do not extract PCs from dummy variables of sovereign wealth funds, bilateral swap agreements, macro-prudential policies, and fixed or crawling peg exchange rate regimes because applying PCA to discrete variables may bias the estimates (Kolenikov and Angeles, 2004). 
selected PCs of the sample of developing countries for all the four subsample periods. ${ }^{19}$ Thirteen macroeconomic or finance-related variables are reduced to six PCs for the 1999-2006 and 1999-2012 samples, and to five PCs for the 20007-2009 and 2010-2012 subsamples. Five trade or industrial structure variables are reduced to two PCs in all the subsamples. ${ }^{20}$

Using these selected PCs and the other potential explanatory variables, we repeated the same regression analyses underlying Tables 2 and 3, and reported the resulting parsimonious models in Table A2 of Appendix 2. Column (2) in each panel of the table reports the results of the estimations where the variables that are not highly correlated with any of the PCs are included in the estimation. ${ }^{21}$ For the 1999-2006 sample, PC2, PC3, and PC4 of the macro/finance variables are significant. $P C 2$ is found to be a positive contributor to IR holdings (Table A2) and it is positively correlated with net FDI liabilities and gross saving (Table A1); implying that both net FDI liabilities and gross saving are positive contributors to IR holdings. The implied gross saving effect is consistent with the finding reported in Table 2. These results indicate that gross saving is a robust variable - it is a significant factor in both the simple OLS estimation and the regression with PCs.

Table 6 summarizes the comparison of the estimation results. The "OLS-FE" column reports the signs of the significant estimates found when individual variables are used in the OLS estimation with country-fixed effects (Table 2). The "PC" column reports the implied signs inferred from OLS exercises with PCs (Tables A1 and A2). For instance, gross saving, net portfolio liabilities, the Joneses variables for Asia and Europe, and the share of fuel exports (in total exports) displayed the same signs from both estimation exercises in the 1999-2006 period. ${ }^{22}$

Overall, the models that include PCs perform relatively well. The within R-squares estimates of the models with PCs are close to those of the OLS-FE models. For all the subsample periods, except for the 2007-2009 period, the signs of many significant variables under the OLS-FE specifications are the same as those implied by the OLS-PC exercise. The 2007-2009 exception is likely due to the instability of estimation results during the GFC period. It is

\footnotetext{
19 To conserve space, the results of the developed country group are not reported. They are available from the authors upon request.

20 Component loadings, that is, correlations between the original variables and PCs, with absolute value smaller than .40 are omitted from presentation for easier interpretation. Hence, the tables show only relatively high correlations.

21 The low levels of correlation suggest they are relatively orthogonal to the chosen PCs.

$22 \mathrm{M}$ /GDP has the consistent sign when it is included in the estimation in addition to the PCs. Note that none of the PCs is highly correlated with M2/GDP (column (2) of TableA2(a)).
} 
noteworthy noting that most of the "recently-discussed" variables that were found significant in the OLS-FE estimations, such as gross saving, Joneses variables, and the dummies for SWF, bilateral swap agreements, and macro-prudential policies, are significant in the estimations with PCs.

Lastly, we calculated the predicted errors of IR holdings, which we use as proxies of reserve over-hoarding, using the estimation results of Table A2. We then regressed the rate of exchange rate depreciation against the U.S. dollar on these estimated errors. Comparable to the results reported in Table 5, the estimated errors from the specifications with PCs are significant predictors of currency depreciation for all the four subsample periods when the average rate of depreciation during the 2010-2012 period is considered. For the 2012 rate of depreciation, the estimated errors from the 2010-12 or 1999-2012 model are significant predictors. ${ }^{23}$

\subsection{Bayesian Model Averaging (BMA)}

While the choice of a parsimonious model based on the statistical significance of parameter estimates seems reasonable, one may say the approach does not explicitly allow for model uncertainty. Suppose there are $p$ possible explanatory variables. These $p$ variables give rise to $2^{p}$ possible model specifications, $M^{i}$ that form the model space $\mathrm{M}=\left\{M^{1}, M^{2}, \ldots\right.$, $\left.M^{2^{p}}\right\}$. As long as the process of selecting appropriate explanatory variables involves some degree of uncertainty, there is uncertainty about which one of these $2^{p}$ models is the true model. ${ }^{24}$

The Bayesian Model Average (BMA) methodology accounts for such model uncertainty in assessing parameter estimates. In essence, the estimate of a parameter is a weighted average of its estimates from all the $2^{p}$ possible model specifications, with the weight of each estimate determined by the performance of the model from which it is obtained. See, for example, Hoeting, et al. (1999), Luca and Magnus (2011), Hoeting (2002), and Montgomery and Nyhan (2010) for a detailed discussion of the methodology. ${ }^{25}$

For each sample period, we labelled the variables that are significant in Table 2 as the "focus regressors," and other insignificant candidate variables as the "auxiliary regressors."

23 The results are qualitatively the same when estimated errors incorporating country-fixed effects are used. Indeed, the predicted levels of reserve holdings from the specifications using a) individual variables and b) PCs have a level of correlation of $90 \%$, except for the $2007-2009$ period $(76 \%)$.

24 The decision of which variable to be excluded involves a trade-off between bias and precision of the estimators of the variables included in the model ("focus variables").

25 Fernández, et al. (2001) on growth model is one of the few economics studies that used the BMA methodology. 
Following the literature, the focus regressors are those believed to be more certain to be in the regression than the auxiliary variables. The BMA estimation will be based on all the possible variable combinations and comes up with the weighted averages of the estimates obtained from these possible model specifications.

Table 7 reports the BMA estimates and their corresponding posterior inclusion probabilities ("PIPs"). The PIP is the posterior probability of including a variable in the model. Under each sample period heading, the estimates of focus regressors are presented first (above the line) followed by those of auxiliary regressors (below). ${ }^{26}$ We follow a convention to include an explanatory variable if its PIP is 0.5 or greater in the model. These admitted variables are marked in the bold font. Note that a PIP larger than 0.5 corresponds to a $t$ ratio of one or greater in absolute value. To conserve space, $t$ ratios are not presented.

There are a few observations from comparing Tables 2 and 7. First, the explanatory variables that are significant in Table 2 are found to be quite robust; that is, PIP $=1.00$ in Table 7. Second, several BMA estimates have signs that are opposite those the corresponding ones in Table 2. ${ }^{27}$ Third, the estimates in Table 7 often have magnitudes differ from the corresponding ones in Table 2. However, we cannot generalize and infer which approach yields estimates that are consistently larger than the other one. [Last, when we use the PIP of 0.5 as the criterion, BMA still identify some other robust variables especially for the 1999-2006 and 1999-2012 models.

Despite some differences, the BMA results are in general comparable to those in Table 2. The differences may be attributed to the fact that our BMA procedure does not control for a) the correlation between potential regressors in estimating all possible model specifications, and b) the country-fixed effects. As argued by Montgomery and Nyhan (2010), despite the usefulness of the estimation technique, BMA should not be regarded as a panacea for model selection. It would best work as an estimation technique to test competing theory-based models or as a robustness check to show that the main estimation results are not overly sensitive to model specifications. As such, we could state that most of the determinants we found significant are robust with the BMA estimation, although the estimation also suggests the possibility of other variables entering

\footnotetext{
26 The signs in parentheses next to variable names are those in Table 2.

27 These estimates are: net portfolio liability position, Joneses X Asia, commodity volatility in the $1999-2006$ model; reserve volatility, net debt liability position, net FDI liability position, and the number of currency crises in the 2007-2009 model; financial exposure, outward direct investment, and the number of banking crises; and SWF and Joneses x Asia in the 1999-2006 period.
} 
the models.

\section{Conclusions}

Our analysis puts to the fore the changing nature of the hoarding of international reserves. We empirically confirmed structural changes associated with new patterns of hoarding IR especially in the aftermath of the global financial crisis. Among the determinants that received more attention in the post-GFC period, we found that the saving rate has been playing an important role in determining the level of IR hoarding even before the GFC - emerging markets with higher saving rates tend to use higher buffers of IR, partially accounting for the higher levels of IR in East Asia in comparison of Latin America. Other variables we newly identified include the accessibility to swap lines, implementations of macro-prudential regulations, the existence of a sovereignty wealth fund, and the attitude towards outward foreign investment.

While there is no end in sight for hoarding reserves, some of the newly identified factors may mitigate eventual reserve accumulation. Some of the macro prudential measures are purported to preemptively prevent excessive credit growth through both macroeconomic and microeconomic countercyclical measures while others are particularly targeted to dwarf the influx of overseas capital to an overheating economy by imposing capital controls. Hence, an implementation of macro-prudential policies may lead to fewer IRs if countries feel less need to hold precautionary IR, or it could lead to more IRs if the policies help prevent a drainage of IRs. Interestingly, we found the negative impact of macro-prudential policies for developed countries and the positive one for developing countries.

The proliferation of SWFs and possible rebalancing of emerging markets that followed aggressive export-led growth before the GFC may reduce reserve/GDP ratios of developing countries, as confirmed in the predictive exercises using the latest data. The robustness of the "Keeping with the Joneses" effect also suggests potential gains from regional and global steps towards deeper use of swap lines and cooperative pooling arrangements.

These predictions, however, should be taken with a grain of salt. Given the dynamic nature of the forces that shape the hoarding of reserves, there is no reason to expect future stability in the patterns of hoarding IR. Thus, on top of the relevance of the new determining factors, one should be aware of the possible shift in the hoarding behavior in the future. 


\section{Appendix 1: Data Definitions}

Macro/Traditional Variables $(\mathrm{X})$ :

Propensity to import - Imports as a ratio to GDP.

Reserve volatility - Standard deviations of the growth of IR holding in five year windows $(t-5$ through $t-1$ ) are used. The data are extracted from WDI and IFS.

Gross saving - Gross saving is used as \% of GDP. WDI and WEO.

Opportunity cost of holding reserves - It is the difference between the long-term government bond yields and the U.S. 10-year government bond yields (Previously, I used the Treasury bill rates, not any more). For the countries for which the long-term bond yields data are not available, "lending rates" from the IFS are used. The data are from WDI and IFS.

Financial and Institutional Variables (Y):

M2 as \% of GDP - M2 as a share of GDP (I used liquid liability ratios in the previous round)

De jure measure of financial openness - The index is based on Chinn and Ito $(2006,2008)$ and downloaded from http://web.pdx.edu/ ito/Chinn-Ito_website.htm .

Gross Portfolio Exposure - The sum of external assets and liabilities divided by GDP. The data are extracted from Lane-Milesi-Ferretti dataset. Previously, we used "net" exposure or change in the net exposure.

Net liabilities for FDI, debt, and portfolio investment - For each of the cross-border investment types, the net liabilities are calculated as <external liability minus external asset>, using the updated dataset of Lane and Milesi-Ferretti (2007 and updates).

\section{Country Characteristic Variables (D):}

Dummies for the fixed/pegged and crawling peg regimes - The Reinhart-Rogoff (2004) index is used to construct the exchange rate regime dummy variables. Their index ranges from 1 "no separate legal tender," to 14 "Freely falling" (with increasing flexibility of exchange rate movement) and is a "de facto" index (in contrast to IMF's "de jure" exchange rate regime classification). Here, as in Cheung and Ito, we aggregate these categories into three groups; namely "floating," "Crawling Peg," and "Fixed/Pegged." The Reinhart and Rogoff index is updated to 2010. For 2011, we assume countries have the same exchange rate regime as in 2010.

Other characteristic dummy variables are not tested because the estimations are conducted with country-fixed effects.

\section{'New' Variables (Z)}

Dummy for the sovereign wealth funds (SWF) - Using the data from the SWF Institute (http://www.swfinstitute.org/fund-rankings/), we assign the value of one for the country and years in which the country of concern possesses a national-level SWF.

Dummy for bilateral swap agreements (SWAP) - This dummy takes the value of one if a country 
is in an agreement of bilateral currency swap (regardless of the currency of the agreement) such as the Fed, the ECB, and the Bank of Japan. The data are compiled using website information.

Dummy for macro prudential policies (MPP) - This dummy takes a value of one if a country has in place any of the macro prudential policies Lim, et al. (2013) compiled.

Gross saving - Gross saving is used as \% of GDP. WDI and WEO.

Commodity TOT Volatility - Using the commodity terms of trade data compiled by Spatafora and Tytell (2009), we use the moving five-year standard deviations (in $t-5$ through $t$-1) of the change in the commodity TOT index as a proxy for commodity TOT volatility. ${ }^{28}$

Joneses' Effects - This variable is supposed to capture regional externality of IR holding and its computation is based on Cheung and Qian (2009). It is essentially the average of IR holding in the region country $i$ belongs to, but it excludes the level of IR holding of country $i$ itself. The regions are: "North and South America," "Europe," "East and South Asia," "Middle-east and North Africa," and "Sub-Saharan Africa."29

Outward direct investment (ODI) - Outward direct investment as a share of GDP. The data are extracted from UNCTAD's database.

Oil exporters - The dummy is assigned for oil exporters defined by the World Bank or Spatafora and Tytell (2009).

\% of commodity exports - The "commodity exports" are the sum of fuel, food, agricultural goods, and minerals, all of which are extracted from WDI. It is shown as the share of total exports.

$\%$ of manufacturing exports - The data are from WDI. It is shown as the share of total exports.

Ratio of goods exports to service exports - Using the BoP data, we calculate the proportion of service exports in goods and service exports. Then, we come up with the ratio as (1 minus service exports as $\%$ of total exports)/(service exports as $\%$ of total exports).

Financial Exposure - We use the ratio of (total external assets + total external liabilities) to GDP. The data are based on Lane and Milesi-Ferretti (2007 and updates).

Currency and Banking Crises - We use the dummy for both currency and banking crisis episodes that are identified in Aizenman and Ito (2013). For the identification of currency crisis, Aizenman and Ito (2013) first calculate the exchange rate market pressure (EMP) against the base country (Aizenman, et al., 2008, Eichengreen, et al. 1995, 1996). For the countries whose data for the EMP are not available, the crisis dummy is supplemented by the currency crisis identification by Reinhart and Rogoff (2009). Their banking crisis data are essentially based on Laeven and Velancia (2008, 2010, 2012). We count the number of past crisis years over $t-1$ through t-5 for each type of crises while assigning weights on the crisis dummies depending on the year. That is, the crisis variables are calculated as: $\mathrm{D}_{\mathrm{c}(t-1)}+.95 * D_{c(t-1)}+.90 * D_{c(t-3)}$ $+.85 * D_{c(t-4)}+.80 * D_{c}(t-5)$. We assume that the weight diminishes by $5 \%$ every year, that is, that the memory of a crisis among policy makers "depreciates" at the annual rate of $5 \%$.

\footnotetext{
28 The original data are available up to 2009, but we obtained more updated data (up to 2011) from the authors. We thank authors for the generosity to share the data.

29 "Europe" includes Western, Central, and Eastern Europe.
} 


\section{Appendix 2: Estimations with the Principal Component Analysis (PCA)}

Because we use many candidate variables to investigate the determinants of IR holding, admittedly, our regression analysis may involve the risk of having some of the right-hand-side variables correlated with each other. Although simple correlation analysis does not report high levels of correlation among the explanatory variables (not reported), it is worthwhile for us to examine if we still obtain similar results once we control for potential multicollinearity.

For that purpose, the principal component analysis (PCA) can be a useful tool. ${ }^{30}$ PCA is a statistical tool that extracts, from a matrix composed of $p$ variables and $n$ samples, orthogonal linear combinations of the variables that capture the widest variance of the variables. In other words, when there is a possibility that some of $p$ variables are correlated with each other, PCA would redefine the axes in a way that the distribution of $p$ variables is captured most successfully. The linear combinations of the variables are called principal components (PCs), and there are as many PCs as the number of the variables tested. The first PC, $Y_{l}$ as shown below, covers the greatest variance of the original variables: $\left(X_{1}, X_{2}, \ldots X_{p}\right)$.

$$
Y_{1}=a_{11} X_{1}+a_{12} X_{2}+\ldots+a_{1 p} X_{p}
$$

The second PC, $Y_{2}$, covers the second greatest variance of the original variables, and there are as many PCs as the number of the original variables $(p)$. As the order of the PC increases, the extent of an incremental increase in the coverage of the variance of the original variables, known as eigenvalues, monotonically decreases while the cumulative coverage of the variance monotonically increases and eventually becomes one for the $p^{\text {th }} \mathrm{PC}^{31}$ Because eigenvalues decline for higher orders of the PCs, certain PCs with higher orders would not be of much use to explain the variation of the original variables. Therefore, using some threshold, one can choose some number, say $k$, of the PCs $(0<k \leq p)$ instead of using all $p$ PCs, so that a smaller number of variables, that is, $k$, can be used to represent the variation of the $p$ number of the original variables. Many researchers often use the Kaiser criterion as the threshold; the PCs whose eigenvalue is less than one will be cut off. Hence, PCA is a useful way to reduce the number of the original variables while the created (reduced number of) PCs are, by definition, orthogonal to each other.

The weights, $a_{i p}$, in equation (A1) are the eigenvectors of the variance-covariance matrix of the original data, also known as "component loadings," indicating the correlation, or covariance, of the original $X_{i}$ with respect to the $\mathrm{PC}$ (that is, $Y_{i}$ ). $a_{i}$ 's are derived with the constraint that their sum of squares equals one. $a_{i}$ 's indicate the correlation of the original $X_{i}$ with the PCs. In other words, the PCs are newly defined variables that represent, that is, are highly correlated with, some of the original $X_{i}$ 's. ${ }^{32}$ For more details on PCA, refer to Anderson (2003) and other statistics textbooks.

Using the PCA, we will examine if we can obtain similar results as in the OLS regression exercises. For that, we will take the following steps.

\footnotetext{
30 We thank Yu-chin Chen for suggesting this.

31 The eigenvalues are the diagonal elements of the variance-covariance matrix of the principal components.

32 The Kaiser-Meyer-Olkin (KMO) measure can be used to determine whether the use of the PCs is appropriate or not. The KMO, which ranges between zero and one, of above 0.5 is often used as the threshold for the appropriateness of the use of PCs.
} 
1. Regroup the candidate determinants to the group of macroeconomic/financial variables; that of variables pertaining to trade/industrial structure; and that of the Joneses effect variables. We do not include in any of the groups the dummy variables for sovereign wealth funds, bilateral swap agreements, macroprudential policies, and fixed or crawling peg exchange rate regimes. ${ }^{33}$

2. Apply the PCA to each of the variable groups for both subsamples of developed and developing countries, and select the PCs using the cut-off eigenvalue of 1 . However, if the PCs chosen with the cut-off eigenvalue of 1 would only yield the cumulated coverage of the variance of the original variables less than $75 \%$, higher orders of PCs would be chosen until the cumulated coverage of the variance becomes greater than $75 \%$.

3. Using all the selected PCs and the other variables that are not used for the PCA, repeat the same exercise as in Tables 2 and 3 , that is, obtain parsimonious estimation models by sequentially dropping the insignificant variables from the specifications. ${ }^{34}$

4. Estimate again with the variables that are only weakly correlated with any of the PCs. ${ }^{35}$

5. Compare the results from Steps 3 and 4 with those of Tables 2 and 3.

As an example, when we apply the PCA to the group of macroeconomic/financial variables for the subsample of developing countries (LDC) from the 1999-2006 period, the Kaiser criterion leads us to obtain six PCs for this group of variables (instead of 13), which covers $78 \%$ of the variation in all of the group's variables (see the bottom row of Table A1(a)). ${ }^{36}$ In Table A1 (a), we can see that the first PC, or $P C l$ (that alone covers $31 \%$ of the variation), is positively correlated with the variables for propensity to import and financial exposure, suggesting that $P C l$ is considered to be a variable that represent the possible risk from trade of both goods and financial assets. ${ }^{37} P C 2$ is positively correlated with net FDI liability position and gross saving (and therefore represents possible safe guard against capital reversals); PC3 is positively correlated with both crisis variables, and so forth. Table A1 (b) report that the group of trade structure variables yields two PCs. $P C 1$ is negatively correlated with the share of manufacturing exports and positively with the shares of fuel exports and commodity exports.

After obtaining PCs, we take the above Step 3 to come up with a parsimonious model by testing all the PCs and other variables and sequentially dropping the insignificant variables from the specifications. We report the result of the parsimonious model in the first column of Table A2 (a). We also estimate the model again including the variables that are only weakly correlated with the PCs such as the variables for the opportunity cost, M2 (as a share of GDP), and net debt liability position. We compare these results with those reported in the first column of Table 2 and report the comparison in Table 4.

\footnotetext{
${ }^{33}$ Strictly speaking, the PCA should be applied primarily to continuous, normally distributed variables. Discrete variables such as categorical variables and dummy variables may bias the estimates (Kolenikov and Angeles, 2004). Dummy variables derived from categorical variables (such as the dummy variables for exchange rate regimes we use) or those which could not have continuous basis could especially bias the estimates. The compositions of the variable groups can be seen in Table A1.

${ }^{34}$ Because the KMO measure indicates that it is not appropriate to obtain the principal components for the Joneses effect variables, these variables are included in the estimations as they were in Tables 2 and 3.

${ }^{35}$ Because these variables are not represented by any of the PCs.

${ }^{36}$ We do not report eigenvalues and the coverages of variables' variations to conserve space. However, they are available upon request.

37 The table omits reporting component loadings with absolute value smaller than 0.40 for easier presentation. Hence, the loadings reported in Table A1 indicate those for 'highly' correlated variables with the PC.
} 
Table A1: Results of the PCA for the LDC Sample

\section{(1) $1999-2006$}

(a): Macro/Traditional variables (\# of variables $=13 ; \mathrm{N}=441 ; \mathrm{KMO}=0.7080$ )*

\begin{tabular}{l|c|c|c|c|c|c}
\hline & $P C 1$ & $P C 2$ & $P C 3$ & $P C 4$ & $P C 5$ & PC6 \\
\hline $\begin{array}{l}\text { Prop. to import } \\
\text { Reserve Vol. } \\
\text { Opp. Cost }\end{array}$ & 0.4091 & & & & 0.7264 & \\
M2 / GDP \\
$\begin{array}{l}\text { Chinn-Ito } \\
\text { N. Port. Liab. Pos. }\end{array}$
\end{tabular}

(b): 'Trade Structure' Variables (\# of variables $=5 ; \mathrm{N}=441 ; \mathrm{KMO}=0.5862$ )*

\begin{tabular}{l|c|c}
\hline & $P C 1$ & $P C 2$ \\
\hline Commodity Volatility & & -0.6208 \\
\% of Manuf. Exports & -0.6132 & \\
Ratio of Good to Service Exp. & & 0.5814 \\
\% of Fuel Exports & 0.4383 & 0.4858 \\
\% of Commodity Exports & 0.6122 & \\
\hline Cumulative coverage & 0.4948 & 0.7779 \\
\hline
\end{tabular}

(2) $2007-2009$

(c): Macro/Traditional variables (\# of variables $=13 ; \mathrm{N}=182 ; \mathrm{KMO}=0.7089$ )*

\begin{tabular}{|c|c|c|c|c|c|}
\hline & $P C 1$ & $P C 2$ & $P C 3$ & $P C 4$ & $P C 5$ \\
\hline $\begin{array}{l}\text { Prop. to import } \\
\text { Reserve Vol. } \\
\text { Opp. Cost } \\
\text { M2 / GDP } \\
\text { Chinn-Ito } \\
\text { N. Port. Liab. Pos. } \\
\text { N. Debt Liab. Pos. } \\
\text { N. FDI Liab. Pos. } \\
\text { Financial Exposure } \\
\text { Gross Saving (\%) } \\
\text { Outward Dir. Invest. } \\
\text { Currency crisis } \\
\text { Banking crisis }\end{array}$ & $\begin{array}{l}0.4503 \\
0.4160\end{array}$ & $\begin{array}{r}-0.4122 \\
0.5750 \\
0.5096\end{array}$ & $\begin{array}{l}0.4190 \\
\\
0.4310 \\
0.4806\end{array}$ & $\begin{array}{l}0.4367 \\
0.4686\end{array}$ & $\begin{array}{l}-0.5160 \\
0.4737\end{array}$ \\
\hline Cumulative coverage & 0.3330 & 0.4721 & 0.5819 & 0.6737 & 0.7524 \\
\hline
\end{tabular}

(d): 'Trade Structure' Variables (\# of variables $=5 ; \mathrm{N}=182 ; \mathrm{KMO}=0.6212$ )*

\begin{tabular}{l|c|c}
\hline & $P C 1$ & $P C 2$ \\
\hline $\begin{array}{l}\text { Commodity Volatility } \\
\text { \% of Manuf. Exports }\end{array}$ & -0.5580 & 0.8272 \\
Ratio of Good to Service Exp. & & \\
\% of Fuel Exports & 0.4482 & -0.5229 \\
$\%$ of Commodity Exports & 0.5574 & \\
\hline Cumulative coverage & 0.5671 & 0.7790 \\
\hline
\end{tabular}

*Notes: Component loadings with absolute value smaller than .40 are omitted from presentation for easier interpretation. "KMO" means the Kaiser-Meyer-Olkin measure of sampling adequacy. 


\section{(3) 2010 - 2012}

(e): Macro/Traditional variables (\# of variables $=13 ; \mathrm{N}=154 ; \mathrm{KMO}=0.7288$ )*

\begin{tabular}{l|c|c|c|c|c}
\hline & $P C 1$ & $P C 2$ & $P C 3$ & $P C 4$ & $P C 5$ \\
\hline $\begin{array}{l}\text { Prop. to import } \\
\text { Reserve Vol. }\end{array}$ & 0.4040 & & & & \\
Opp. Cost & & & & 0.5390 & \\
M2 / GDP & & & 0.4881 & & \\
Chinn-Ito & -0.5048 & & & \\
$\begin{array}{l}\text { N. Port. Liab. Pos. } \\
\text { N. Debt Liab. Pos. } \\
\text { N. FDI Liab. Pos. }\end{array}$ & & & & & \\
$\begin{array}{l}\text { Financial Exposure } \\
\text { Gross Saving (\%) }\end{array}$ & 0.4430 & 0.5437 & & & \\
$\begin{array}{l}\text { Outward Dir. Invest. } \\
\text { Currency crisis } \\
\text { Banking crisis }\end{array}$ & 0.4158 & 0.4784 & & & \\
\hline Cumulative coverage & 0.3589 & 0.5014 & 0.5997 & 0.6884 & 0.7627 \\
\hline
\end{tabular}

(f): ‘Trade Structure’ Variables (\# of variables $=5 ; \mathrm{N}=154 ; \mathrm{KMO}=0.6837$ )*

\begin{tabular}{l|c|c}
\hline & $P C 1$ & $P C 2$ \\
\hline $\begin{array}{l}\text { Commodity Volatility } \\
\text { \% of Manuf. Exports }\end{array}$ & -0.5622 & -0.6740 \\
Ratio of Good to Service Exp. & & 0.5460 \\
\% of Fuel Exports & 0.4203 & 0.4585 \\
\% of Commodity Exports & 0.5637 & \\
\hline Cumulative coverage & 0.5839 & 0.8378 \\
\hline
\end{tabular}

\section{(4) $1999-2012$}

(g): Macro/Traditional variables (\# of variables $=13 ; \mathrm{N}=777 ; \mathrm{KMO}=0.7451$ )*

\begin{tabular}{|c|c|c|c|c|c|c|}
\hline & $P C 1$ & $P C 2$ & $P C 3$ & $P C 4$ & $P C 5$ & PC6 \\
\hline $\begin{array}{l}\text { Prop. to import } \\
\text { Reserve Vol. } \\
\text { Opp. Cost } \\
\text { M2 / GDP } \\
\text { Chinn-Ito } \\
\text { N. Port. Liab. Pos. } \\
\text { N. Debt Liab. Pos. } \\
\text { N. FDI Liab. Pos. } \\
\text { Financial Exposure } \\
\text { Gross Saving (\%) } \\
\text { Outward Dir. Invest. } \\
\text { Currency crisis } \\
\text { Banking crisis }\end{array}$ & 0.4046 & $\begin{array}{l}0.5458 \\
0.4581\end{array}$ & $\begin{array}{l}0.5968 \\
0.5586\end{array}$ & 0.4255 & $\begin{array}{l}-0.7101 \\
0.4461\end{array}$ & $\begin{array}{l}-0.4289 \\
0.4658\end{array}$ \\
\hline Cumulative coverage & 0.3248 & 0.4646 & 0.5722 & 0.6568 & 0.7303 & 0.7864 \\
\hline
\end{tabular}

(h): 'Trade Structure' Variables ( $\#$ of variables $=5 ; \mathrm{N}=777 ; \mathrm{KMO}=0.6106$ )*

\begin{tabular}{l|c|c}
\hline & $P C 1$ & $P C 2$ \\
\hline $\begin{array}{l}\text { Commodity Volatility } \\
\text { \% of Manuf. Exports }\end{array}$ & -0.5880 & -0.6910 \\
Ratio of Good to Service Exp. & & 0.5110 \\
\% of Fuel Exports & 0.4576 & 0.4442 \\
\% of Commodity Exports & 0.5878 & \\
\hline Cumulative coverage & 0.5209 & 0.7808 \\
\hline
\end{tabular}

*Notes: Component loadings with absolute value smaller than .40 are omitted from presentation for easier interpretation. "KMO" means the Kaiser-Meyer-Olkin measure of sampling adequacy. 
Table A2: Determinants of IR holding Using Principal Components - LDC

(a) $1999-2006$

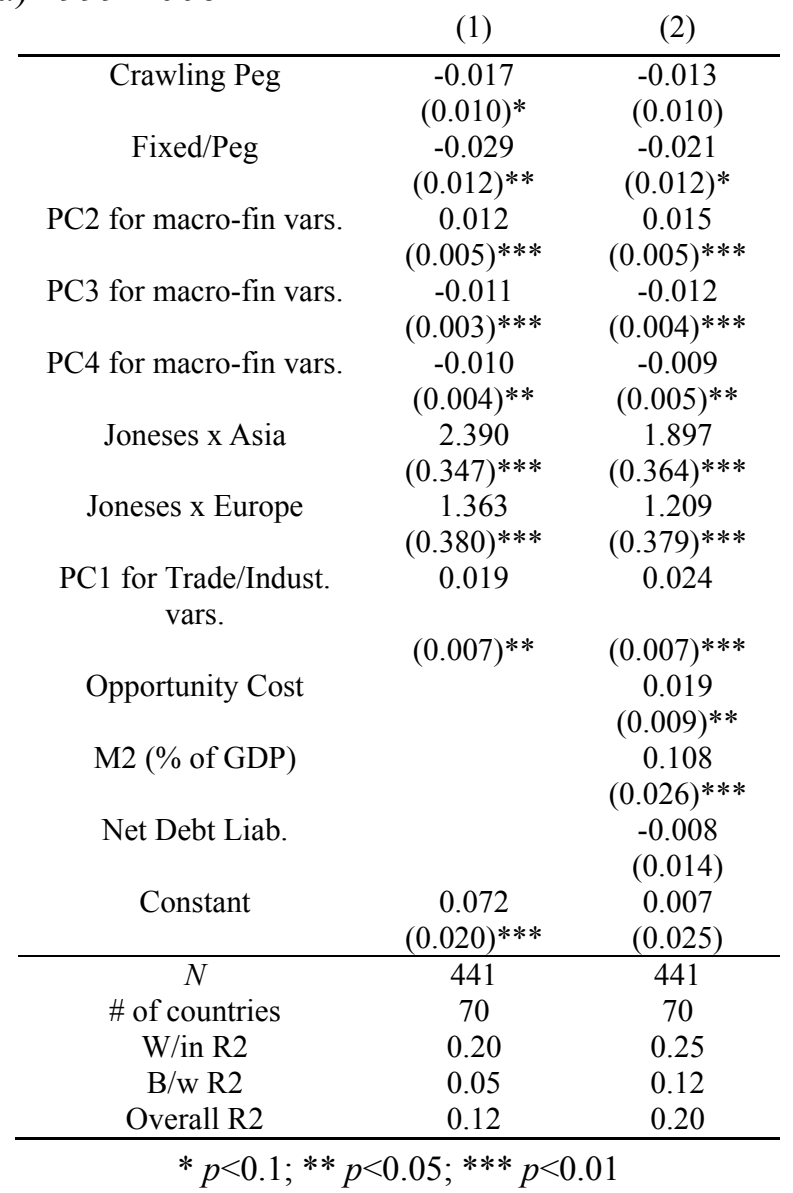

(b) $2007-2009$

\begin{tabular}{ccc} 
& $(1)$ & $(2)$ \\
\hline Swap agr., dummy & 0.055 & 0.054 \\
& $(0.026)^{* *}$ & $(0.026)^{* *}$ \\
PC2 for macro-fin vars. & 0.062 & 0.052 \\
& $(0.019)^{* * *}$ & $(0.022)^{* *}$ \\
Joneses x Asia & -2.522 & -2.618 \\
& $(0.890)^{* * *}$ & $(0.879)^{* * *}$ \\
M2 (\% of GDP) & & 0.187 \\
& & $(0.124)$ \\
Net Debt Liab. & & 0.128 \\
& & $(0.085)$ \\
Constant & 0.344 & 0.245 \\
& $(0.038)^{* * *}$ & $(0.088)^{* * *}$ \\
\hline$N$ & 182 & 182 \\
\# of countries & 67 & 67 \\
W/in R2 & 0.16 & 0.20 \\
B/w R2 & 0.12 & 0.00 \\
Overall R2 & 0.12 & 0.00 \\
$* p<0.1 ; * * p<0.05 ; * * * p<0.01$ \\
\end{tabular}


Table A2 (cont'd): Determinants of IR holding Using Principal Components - LDC

(c) $2010-2012$

\begin{tabular}{ccc} 
& $(1)$ & $(2)$ \\
\hline SWF, dummy & 0.071 & 0.076 \\
Swap agr., dummy & $(0.034)^{* *}$ & $(0.034)^{* *}$ \\
& -0.035 & -0.026 \\
PC2 for macro-fin vars. & $0.016)^{* *}$ & $(0.017)$ \\
& $(0.013)^{* * *}$ & 0.050 \\
PC4 for macro-fin vars. & -0.033 & $(0.015)^{* * *}$ \\
& $(0.010)^{* * *}$ & -0.033 \\
Joneses x Europe & -2.120 & -2.363 \\
& $(1.009)^{* *}$ & $(1.012)^{* *}$ \\
Joneses x MENA & 0.632 & 0.660 \\
& $(0.113)^{* * *}$ & $(0.122)^{* * *}$ \\
M2 (\% of GDP, t-1) & & 0.001 \\
& & $(0.079)$ \\
Net Port. Liab. & & 0.053 \\
& & $(0.113)$ \\
Net Debt Liab. & & -0.092 \\
& & $(0.046)^{*}$ \\
Constant & 0.304 & 0.295 \\
& $(0.046)^{* * *}$ & $(0.074)^{* * *}$ \\
\hline$N$ & 154 & 154 \\
\# of countries & 58 & 58 \\
W/in R2 & 0.39 & 0.42 \\
B/w R2 & 0.05 & 0.04 \\
Overall R2 & 0.06 & 0.05 \\
$* p<0.1 ; * * p<0.05 ; * * * p<0.01$ \\
\hline
\end{tabular}

(d) 1999-2012

\begin{tabular}{|c|c|c|}
\hline & (1) & (2) \\
\hline SWF, dummy & $\begin{array}{c}-0.027 \\
(0.014)^{*}\end{array}$ & $\begin{array}{c}-0.026 \\
(0.014)^{*}\end{array}$ \\
\hline Macro Prud.Pol., dummy & $\begin{array}{c}0.022 \\
(0.007)^{* * *}\end{array}$ & $\begin{array}{c}0.019 \\
(0.007)^{* * * *}\end{array}$ \\
\hline Fixed/Peg & $\begin{array}{c}-0.028 \\
(0.009)^{* * *}\end{array}$ & $\begin{array}{c}-0.029 \\
(0.009)^{* * * *}\end{array}$ \\
\hline PC1 for macro-fin vars. & $\begin{array}{c}0.041 \\
(0.004)^{* * *}\end{array}$ & $\begin{array}{c}0.057 \\
(0.006)^{* * *}\end{array}$ \\
\hline PC2 for macro-fin vars. & $\begin{array}{c}0.014 \\
(0.004)^{* * *}\end{array}$ & $\begin{array}{c}0.016 \\
(0.005)^{* * *}\end{array}$ \\
\hline PC4 for macro-fin vars. & $\begin{array}{c}-0.013 \\
(0.004)^{* * *}\end{array}$ & $\begin{array}{c}-0.011 \\
(0.004)^{* * * *}\end{array}$ \\
\hline PC5 for macro-fin vars. & $\begin{array}{c}-0.010 \\
(0.004)^{* * *}\end{array}$ & $\begin{array}{c}-0.010 \\
(0.004)^{* *}\end{array}$ \\
\hline Joneses x Asia & $\begin{array}{c}1.037 \\
(0.175)^{* * *}\end{array}$ & $\begin{array}{c}1.018 \\
(0.175)^{* * *}\end{array}$ \\
\hline Joneses x West Hem. & $\begin{array}{c}0.470 \\
(0.236)^{* *}\end{array}$ & $\begin{array}{c}0.367 \\
(0.241)\end{array}$ \\
\hline PC1 for Trade/Indust. Vars. & $\begin{array}{c}0.014 \\
(0.006)^{* *}\end{array}$ & $\begin{array}{c}0.013 \\
(0.006)^{* *}\end{array}$ \\
\hline Net Port. Liab. & & $\begin{array}{c}-0.041 \\
(0.040)\end{array}$ \\
\hline Net Debt Liab. & & $\begin{array}{l}-0.019 \\
(0.016)\end{array}$ \\
\hline Outward Direct Inv. & & $\begin{array}{c}-0.391 \\
(0.117)^{* * *}\end{array}$ \\
\hline Constant & $\begin{array}{c}0.163 \\
(0.011)^{* * *}\end{array}$ & $\begin{array}{c}0.170 \\
(0.012)^{* * *}\end{array}$ \\
\hline$N$ & 777 & 777 \\
\hline \# of countries & 73 & 73 \\
\hline W/in R2 & 0.29 & 0.30 \\
\hline $\mathrm{B} / \mathrm{w} \mathrm{R} 2$ & 0.25 & 0.29 \\
\hline Overall R2 & 0.37 & 0.42 \\
\hline
\end{tabular}




\section{References}

Aizenman, J., and H. Ito. 2013. Living with the Trilemma Constraint: Relative Trilemma Policy Divergence, Crises, and Output Losses for Developing Countries. NBER Working Paper No. 19448 (September). Cambridge: National Bureau of Economic Research, forthcoming, Journal of International Money and Finance.

Aizenman, J., M. D. Chinn, and H. Ito. 2008. "Assessing the Emerging Global Financial Architecture: Measuring the Trilemma's Configurations Over Time." NBER Working Paper \#14533. Cambridge: National Bureau of Economic Research.

Aizenman, J., M. D. Chinn, and H. Ito. 2010. "The Emerging Global Financial Architecture: Tracing and Evaluating the New Patterns of the Trilemma's Configurations" (with Joshua Aizenman and Menzie Chinn), Journal of International Money and Finance, Vol. 29, No. 4, p. 615-641 (2010).

Aizenman, J., Y. Jinjarak, and N. Marion. 2014. "China's Growth, Stability, and Use of International Reserves. NBER Working Paper \#19739. Cambridge: National Bureau of Economic Research, Open Economies Review, 25: 407-428

Aizenman, J. and J. Lee. 2007. "International Reserves: Precautionary Versus Mercantilist Views, Theory and Evidence," Open Economies Review 18, 191-214.

Aizenman, Joshua, Yeonho Lee, and Youngseop Rhee. 2007. "International Reserves Management and Capital Mobility in a Volatile World: Policy Considerations and a Case Study of Korea," Journal of the Japanese and International Economies, 21, 1-15.

Aizenman, Joshua, and Nancy Marion. 2003. "The High demand for International Reserves in the Far East: What's Going On?" Journal of the Japanese and International Economies, 17, 370-400.

Aizenman, Joshua, and Nancy Marion. 2004. "International Reserve Holdings with Sovereign Risk and Costly Tax Collection," The Economic Journal, 114, 569-591.

Aizenman J. and G. Pasricha. 2013. "Why do emerging markets liberalize capital outflow controls? Fiscal versus net capital flows concerns" Journal of International Money and Finance, 2013, 39, pp: $28-64$.

Anderson, T. W. 2003. An Introduction to Multivariate Statistical Analysis, 3rd Edition, Wiley Series in Probability and Statistics, New York: Wiley.

Bahmani-Oskooee, Mohsen. 1988. "Oil Price Shocks and Stability of the Demand For International Reserves," Journal of Macroeconomics, 10, 633-41.

Bruno, V. and H.S. Shin. 2014. "Capital Flows and the Risk-taking Channel of Monetary Policy, mimeo, Princeton University.

Bussière, M., G. Cheng, M.D. Chinn, and N. Lisack. 2014. "For a Few Dollars More: Reserves and Growth in Times of Crises," National Bureau of Economic Research Working Paper \#19791. Cambridge, MA: National Bureau of Economic Research.

Calvo Guillermo, Alejandro Izquierdo and Luis-Fernando Mejía, 2004. "On the empirics of Sudden Stops: the relevance of balance-sheet effects," Proceedings, Federal Reserve Bank of San Francisco.

Cheung, Yin-Wong and Hiro Ito. 2009. "Cross-sectional analysis on the determinants of international reserves accumulation.” International Economic Journal, Vol. 23, No. 4, p. 447-481. December 2009).

Cheung, Yin-Wong and Hiro Ito. 2008. "Hoarding of International Reserves: A Comparison of the Asian and Latin American Experiences," In Ramkishen S. Rajan, Shandre Thangavelu, and Rasyad A Parinduri (eds), Exchange Rate, Monetary and Financial Issues and Policies in Asia, World Scientific Press, p. 77-115.

Cheung, Yin-Wong and Xingwang Qian. 2009. "Hoarding of International Reserves: Mrs Machlup's Wardrobe and the Joneses. Review of International Economics, 17(4), 824-843.

Cheung, Yin-Wong and Rajeswari Sengupta, 2011, Accumulation of Reserves and Keeping Up with the Joneses: The Case of LATAM Economies, International Review of Economics \& Finance 20 (Jan), 19-31.

Cheung, Yin-Wong and Clement Yuk-Pang Wong. 2008. "Are All Measures of International Reserves 
Created Equal? An Empirical Comparison of International Reserve Ratios," Economics: The Open-Access, Open-Assessment E-Journal, Vol. 2, 2008-15.

http://www.economics-ejournal.org/economics/journalarticles/2008-15.

Chinn, Menzie D., and Hiro Ito. 2006. "What Matters for Financial Development? Capital Controls, Institutions, and Interactions," Journal of Development Economics, 81, 163-192.

Chinn, Menzie D., and Hiro Ito. 2008. "A New Measure of Financial Openness," Journal of Comparative Policy Analysis, Volume 10, Issue 3 (September), 309 - 322.

Courchene, Thomas J., and G.M. Youssef. 1967. "The Demand for International Reserves," Journal of Political Economy, 75, 404-413.

de Beaufort Wijnholds, J. Onno and Arie Kapteyn. 2001. "International Reserve Adequacy in Emerging Market Economies", IMF Working Paper 01/43.

Dooley, Michael P., David Folkerts-Landau, and Peter Garber. 2005. "International Financial Stability: Asia, Interest Rates, and the Dollar," Deutsche Bank Global Research.

Dooley, Michael P., David Folkerts-Landau, and Peter Garber. 2009. "Bretton Woods II Still Defines The International Monetary System," Pacific Economic Review, Blackwell Publishing, vol. 14(3), 297-311, 08.

Eichengreen, B., A. Rose, and C. Wyplosz. 1995. Exchange Market Mayhem: The Antecedents and Aftermaths of Speculative Attacks. Economic Policy. 21 (October). pp. 249-312.

Eichengreen, B., A. Rose, and C. Wyplosz. 1996. Contagious Currency Crises: First Tests. Scandinavian Journal of Economics. 98 (4). pp. 463-484.

Feldstein, Martin. 1999. "A Self-Help Guide for Emerging Markets," Foreign Affairs, 78, 93 - 109.

Flood, Robert P., and Peter M. Garber. 1984. "Collapsing Exchange Rate Regimes: Some Linear Examples," Journal of International Economics, 17, August, 1-13.

Flood, Robert P., and Nancy Marion. 2002. "Holding International reserves in an Era of High Capital Mobility," IMF Working Paper 02/62.

Frenkel, Jacob A.. 1980. "International Reserves Under Pegged Exchange Rates and Managed Float: Corrections and Extensions," Journal of Monetary Economic,s 6, 295-302.

Frenkel, Jacob A.. 1974a. "The Demand for International Reserves by Developed and Less-Developed Countries," Economica, 41, 14-24.

Frenkel, Jacob A.. 1974b. "Openness and the Demand for International Reserves," in Robert Z. Albier (Ed.), National Monetary Policies and the International Financial System, University of Chicago Press, Chicago.

Frenkel, Jacob A. and Boyan Jovanovic. 1981. "Optimal International reserves: A Stochastic Framework," Economic Journal, 91, 507-14.

Heller, Heinz Robert. 1966. “Optimal International Reserves,” Economic Journal, 76, 296-311.

Heller, Heinz Robert. 1968. "The Transactions Demand for International Means of Payment," Journal of Political Economy, 76, 141-145.

Hoeting, J. 2002. Methodology for Bayesian Model Averaging: An Update, In Proceedings - Manuscripts of invited paper presentations, International Biometric Conference, Freiburg, Germany, 231-240.

Hoeting, J. A., D. Madigan, A. E. Raftery, and C. T. Volinsky. 1999. "Bayesian Model Averaging: A Tutorial." Statistical Science 14: 382-417.

Johnson, Harry G.. 1958. International Trade and Economic Growth: Studies in Pure Theory, Harvard University Press: Cambridge.

Kelly, Michael G. 1970. "The Demand for International reserves," American Economic Review, 59, 655-667.

Kolenikov S, Angeles G. 2004. "The Use of Discrete Data in PCA: Theory, Simulations, and Applications to Socioeconomic Indices," Working Paper of MEASURE/Evaluation project, No. WP-04-85, Carolina Population Center, UNC.

Laeven, L. and F. Valencia. 2010. Resolution of Banking Crises: The Good, the Bad, and the Ugly. IMF Working Paper 10/146. Washington, DC: International Monetary Fund.

Laeven, L. and F. Valencia. 2008. "Systematic Banking Crises: A New Database," IMF Working Paper 
WP/08/224, Washington, D.C.: International Monetary Fund.

Laeven, L. and F. Valencia. 2010. "Resolution of Banking Crises: The Good, the Bad, and the Ugly," IMF Working Paper No. 10/44. Washington, D.C.: International Monetary Fund.

Laeven, L. and F. Valencia. 2012. "Systematic Banking Crises: A New Database," IMF Working Paper WP/12/163, Washington, D.C.: International Monetary Fund.Levy-Yeyati, E. and F. Sturzenegger. 2003. "To float or to fix: Evidence on the impact of exchange rate regimes on growth." The American Economic Review 93(4): 1173-1193.

Lane, Philip R., and Dominic Burke. 2001. "The Empirics of Foreign International Reserves," Open Economies Review, 12, 423-434.

Lane, P., and G. M. Milesi-Ferretti. 2007. The External Wealth of Nations Mark II: Revised and Extended Estimates of Foreign Assets and Liabilities, 1970-2004. Journal of International Economics 73(2): 223-250.

Lim, C. H., I. Krznar, F. Lipinsky, A. Otani, and X. Yu. 2013. "The Macroprudential Framework: Policy Responsiveness and Institutional Arrangements." IMF Working Paper, WP/13/166. Washington, D.C.: International Monetary Fund.

Lizondo, Jose Saul, and Mathieson, Donald J. 1987. "The Stability of the Demand for International Reserves," Journal of International Money Finance, 6, 251-282.

Luca, G. D. and J. R. Magnus. 2011. "Bayesian Model Averaging and Weighted-average Least Squares: Equivariance, Stability, and Numerical Issues. The Stata Journal 11. Number 2, pp. 518-544.

Obstfeld, M., Shambaugh, J. C. and Taylor, A. M. 2010. "Financial Stability, the Trilemma, and International Reserves." American Economic Journal: Macroeconomics, 2: 57-94.

Machlup, Fritz. 1966. "The Need for Monetary Reserves," Reprints in International Finance 5. Princeton University.

Montgomery, J. and Brendan Nyhan. 2010. "Bayesian Model Averaging: Theoretical Developments and Practical Applications." Political Analysis 18(2): 245-270.

Ostry, Jonathan D., Atish R. Ghosh, Karl Habermeier, Luc Laeven, Marcos Chamon, Mahvash S. Qureshi, and Annamaria Kokenyne. 2011. "Managing Capital Inflows: What Tools to Use?," IMF Staff Discussion Note, SND/11/06.

Ostry, Jonathan D., Atish Ghosh, Karl Habermeier, Marcos Chamon, Mahvash S. Qureshi, and Dennis B.S. Reinhardt. 2010. "Capital Inflows: The Role of Controls," IMF Staff Position Note 10/04.

Park, Y. C. 2010. "Reform of the Global Regulatory System: Perspectives of East Asia's Emerging Economies, Proceedings, Annual World Bank Conference on Development Economics, pp. 187-212.

Reinhart, C. M. and K. S. Rogoff. 2004. "The Modern History of Exchange Rate Arrangements: A Reinterpretation," The Quarterly Journal of Economics, MIT Press, vol. 119(1), pages 1-48, February.

Roubini, Nouriel, and Jeffrey Sachs. 1989. "Government Spending and Budget Deficits in the Industrial Countries," Economic Policy, 8, 99-132.

Spatafora, N. and I. Tytell. 2009. "Commodity Terms of Trade: The History of Booms and Busts. ." IMF Working Paper, WP/09/205. Washington, D.C.: International Monetary Fund.

The Strategy, Policy, and Review Department, IMF (2011), "Recent Experiences in Managing Capital Inflows - Cross-Cutting Themes and Possible Policy Framework," IMF Policy Paper, http://www.imf.org/external/np/pp/eng/2011/021411a.pdf. 
Table 1: Determinants of Holdings of International Reserves -- Developing Countries

\begin{tabular}{ccccc}
\hline & $1999-2006$ & $2007-09$ & $2010-12$ & $1999-2012$ \\
\hline Propensity to Import (t-1) & 0.098 & 0.303 & -0.117 & 0.107 \\
& $(0.035)^{* * *}$ & $(0.160)^{*}$ & $(0.060)^{*}$ & $(0.031)^{* * *}$ \\
Reserve Volatility & -0.013 & 0.261 & -0.147 & -0.019 \\
& $(0.007)^{*}$ & $(0.187)$ & $(0.212)$ & $(0.008)^{* *}$ \\
M2 (\% of GDP, t-1) & 0.142 & 0.050 & 0.150 & 0.233 \\
& $(0.026)^{* * *}$ & $(0.145)$ & $(0.094)$ & $(0.022)^{* * *}$ \\
Net Port. Liab.(t-1) & -0.101 & 0.065 & -0.151 & 0.023 \\
& $(0.040)^{* *}$ & $(0.127)$ & $(0.127)$ & $(0.035)$ \\
Constant & 0.064 & 0.029 & 0.214 & 0.024 \\
& $(0.018)^{* * *}$ & $(0.098)$ & $(0.072)^{* * *}$ & $(0.016)$ \\
\hline$N$ & 441 & 182 & 154 & 777 \\
\# of countries & 70 & 67 & 58 & 73 \\
Overall R2 & 0.56 & 0.34 & 0.15 & 0.58 \\
W/in R2 & 0.16 & 0.06 & 0.07 & 0.23 \\
\hline
\end{tabular}

Notes: $* p<0.1 ; * * p<0.05 ; * * * p<0.01$. Estimated with country fixed effects. All the explanatory variables are lagged by one year to avoid endogeneity. 
Table 2: Determinants of Holdings of International Reserves - Developing Countries

\begin{tabular}{|c|c|c|c|c|}
\hline & $\begin{array}{c}(1) \\
1999-2006 \\
\end{array}$ & $\begin{array}{c}(2) \\
2007-2009 \\
\end{array}$ & $\begin{array}{c}(3) \\
2010-2012 \\
\end{array}$ & $\begin{array}{c}(4) \\
1999-2012 \\
\end{array}$ \\
\hline Propensity to Import & $\begin{array}{c}0.079 \\
(0.035) * *\end{array}$ & $\begin{array}{c}0.398 \\
(0.47) * * *\end{array}$ & & $\begin{array}{c}0.096 \\
(0.031) * * *\end{array}$ \\
\hline Reserve Volatility & & $\begin{array}{c}0.353 \\
(0.167)^{* *}\end{array}$ & & $\begin{array}{c}-0.021 \\
(0.008)^{* * *}\end{array}$ \\
\hline Opportunity Cost & & $\begin{array}{c}0.042 \\
(0.024)^{*}\end{array}$ & & \\
\hline Fixed/Peg & & & & $\begin{array}{c}-0.026 \\
(0.008)^{* * *}\end{array}$ \\
\hline $\mathrm{M} 2(\%$ of GDP $)$ & $(0.025)^{* * *}$ & & & $(0.026)^{* * *}$ \\
\hline Net Portfolio Liability Pos. & $\begin{array}{c}-0.137 \\
(0.038)^{* * *}\end{array}$ & & & \\
\hline Net Debt Liability Pos. & & $\begin{array}{c}0.169 \\
(0.073)^{* *}\end{array}$ & & \\
\hline Net FDI Liability Pos. & & $\begin{array}{c}0.132 \\
(0.081)\end{array}$ & & \\
\hline Financial exposure & & & $\begin{array}{c}-0.048 \\
(0.017)^{* * *}\end{array}$ & $\begin{array}{c}0.010 \\
(0.004)^{* * *}\end{array}$ \\
\hline De jure financial openness & & $\begin{array}{c}-0.206 \\
(0.083)^{* *}\end{array}$ & & \\
\hline $\begin{array}{l}\text { Sovereign Wealth Funds, } \\
\text { dummy }\end{array}$ & & & $\begin{array}{c}0.082 \\
(0.033)^{* *}\end{array}$ & $\begin{array}{c}-0.024 \\
(0.013)^{*}\end{array}$ \\
\hline $\begin{array}{l}\text { Bilateral swap agreements, } \\
\text { dummy }\end{array}$ & & & $\begin{array}{l}-0.026 \\
(0.015)^{*}\end{array}$ & \\
\hline $\begin{array}{l}\text { Macro Prudential Policy } \\
\text { dummy }\end{array}$ & & & & $\begin{array}{c}0.017 \\
(0.007)^{* *}\end{array}$ \\
\hline Gross saving & $\begin{array}{c}0.159 \\
(0.046)^{* * *}\end{array}$ & $\begin{array}{c}0.526 \\
(0.202)^{* *}\end{array}$ & $\begin{array}{c}0.235 \\
(0.091)^{* *}\end{array}$ & $\begin{array}{c}0.280 \\
(0.043)^{* * *}\end{array}$ \\
\hline Outward Direct Inv. & $\begin{array}{c}-0.170 \\
(0.077)^{* *}\end{array}$ & & $\begin{array}{c}0.536 \\
(0.176)^{* * *}\end{array}$ & \\
\hline Joneses x Asia & $\begin{array}{c}1.588 \\
(0.348)^{* * *}\end{array}$ & $\begin{array}{c}-2.150 \\
(0.894)^{* *}\end{array}$ & & $\begin{array}{c}0.619 \\
(0.170)^{* * *}\end{array}$ \\
\hline Joneses x Europe & $\begin{array}{c}0.973 \\
(0.351)^{* * *}\end{array}$ & & $\begin{array}{c}-2.506 \\
(0.968)^{* *}\end{array}$ & $\begin{array}{c}-0.672 \\
(0.302)^{* *}\end{array}$ \\
\hline Joneses x MENA & & & $\begin{array}{c}0.650 \\
(0.107)^{* * *}\end{array}$ & \\
\hline$\%$ of fuel export & $\begin{array}{c}0.113 \\
(0.046)^{* *}\end{array}$ & & & $\begin{array}{c}0.182 \\
(0.044)^{* * *}\end{array}$ \\
\hline Commodity Volatility & $\begin{array}{c}0.065 \\
(0.031)^{* *}\end{array}$ & & & \\
\hline$\%$ of commodity exports & & $\begin{array}{c}0.269 \\
(0.120)^{* *}\end{array}$ & & \\
\hline $\begin{array}{l}\text { \# of Currency crisis } \\
(\mathrm{t}-5 \mid \mathrm{t}-1)\end{array}$ & & $\begin{array}{c}0.056 \\
(0.024)^{* *}\end{array}$ & & \\
\hline \# of Banking crisis & & & $\begin{array}{c}-0.051 \\
(0.010)^{* * *}\end{array}$ & \\
\hline Constant & $\begin{array}{c}-0.051 \\
(0.023)^{* *}\end{array}$ & $\begin{array}{l}-0.027 \\
(0.155)\end{array}$ & $\begin{array}{l}0.359 \\
(0.052)^{* * *}\end{array}$ & $\begin{array}{l}-0.024 \\
(0.021)\end{array}$ \\
\hline$N$ & 441 & 182 & 154 & 777 \\
\hline \# of countries & 70 & 67 & 58 & 73 \\
\hline Between R2 & 0.21 & 0.01 & 0.01 & 0.48 \\
\hline Within R2 & 0.27 & 0.35 & 0.47 & 0.35 \\
\hline Overall R2 & 0.31 & 0.01 & 0.01 & 0.54 \\
\hline
\end{tabular}

Notes: ${ }^{*} p<0.1 ; * * p<0.05 ; * * * p<0.01$. Estimated with country fixed effects. All the explanatory variables, except for reserve volatility and currency and banking crises, are lagged by one year to avoid endogeneity. 


\section{Table 3: Determinants of Holdings of International Reserves - Developed Countries}

\begin{tabular}{|c|c|c|c|c|}
\hline & $\begin{array}{c}(1) \\
1999-2006 \\
\end{array}$ & $\begin{array}{c}(2) \\
2007-2009 \\
\end{array}$ & $\begin{array}{c}(3) \\
2010-2012 \\
\end{array}$ & $\begin{array}{c}(4) \\
1999-2012 \\
\end{array}$ \\
\hline Propensity to Import & & $\begin{array}{c}-0.568 \\
(0.245)^{* *}\end{array}$ & & \\
\hline Reserve Volatility & $\begin{array}{c}0.230 \\
(0.054)^{* * *}\end{array}$ & & $\begin{array}{c}0.864 \\
(0.283)^{* * *}\end{array}$ & \\
\hline Opportunity cost & $\begin{array}{c}0.061 \\
(0.012)^{* * *}\end{array}$ & $\begin{array}{c}-0.155 \\
(0.038)^{* * *}\end{array}$ & $\begin{array}{c}-0.047 \\
(0.019)^{* *}\end{array}$ & $\begin{array}{c}-0.070 \\
(0.014)^{* * *}\end{array}$ \\
\hline $\mathrm{M} 2(\%$ of GDP) & & $\begin{array}{c}-0.110 \\
(0.031)^{* * *}\end{array}$ & & $\begin{array}{c}-0.083 \\
(0.017)^{* * *}\end{array}$ \\
\hline Net Portfolio Liability Pos. & & & $\begin{array}{c}-0.148 \\
(0.047)^{* * *}\end{array}$ & \\
\hline Net Debt Liability Pos. & $\begin{array}{c}0.027 \\
(0.013)^{* *}\end{array}$ & $\begin{array}{c}0.131 \\
(0.035)^{* * *}\end{array}$ & $\begin{array}{c}-0.167 \\
(0.031)^{* * *}\end{array}$ & $\begin{array}{c}-0.099 \\
(0.013)^{* * *}\end{array}$ \\
\hline Financial exposure & $\begin{array}{l}-0.003 \\
(0.002)^{*}\end{array}$ & $\begin{array}{c}-0.018 \\
(0.004)^{* * *}\end{array}$ & $\begin{array}{c}-0.031 \\
(0.010)^{* * *}\end{array}$ & \\
\hline De jure financial openness & $\begin{array}{c}0.275 \\
(0.090)^{* * *}\end{array}$ & $\begin{array}{c}-1.219 \\
(0.241)^{* * *}\end{array}$ & & $\begin{array}{c}0.548 \\
(0.145)^{* * *}\end{array}$ \\
\hline $\begin{array}{l}\text { Sovereign wealth fund, } \\
\text { dummy }\end{array}$ & $\begin{array}{l}-0.036 \\
(0.011)^{* * *}\end{array}$ & & & \\
\hline $\begin{array}{c}\text { Bilateral swap agreements, } \\
\text { dummy }\end{array}$ & & $\begin{array}{c}0.051 \\
(0.009)^{* * *}\end{array}$ & & $\begin{array}{c}0.043 \\
(0.010)^{* * *}\end{array}$ \\
\hline $\begin{array}{l}\text { Macro Prudential Policy, } \\
\text { dummy }\end{array}$ & $\begin{array}{l}-0.012 \\
(0.006)^{*}\end{array}$ & & & \\
\hline Gross saving & $\begin{array}{c}-0.311 \\
(0.091)^{* * *}\end{array}$ & & $\begin{array}{c}-1.451 \\
(0.395)^{* * *}\end{array}$ & \\
\hline Outward Direct Inv. & & & $\begin{array}{c}-0.428 \\
(0.091)^{* * *}\end{array}$ & $\begin{array}{c}-0.159 \\
(0.056)^{* * *}\end{array}$ \\
\hline Joneses x Asia & $\begin{array}{c}0.963 \\
(0.241)^{* * *}\end{array}$ & & & $\begin{array}{c}0.918 \\
(0.238)^{* * *}\end{array}$ \\
\hline Joneses x Europe & $\begin{array}{c}-0.549 \\
(0.179)^{* * *}\end{array}$ & & & \\
\hline Commodity Volatility & $\begin{array}{c}-0.201 \\
(0.051)^{* * *}\end{array}$ & & & \\
\hline$\%$ of manufacturing export & $\begin{array}{c}0.153 \\
(0.057)^{* * *}\end{array}$ & $\begin{array}{c}0.667 \\
(0.389)^{*}\end{array}$ & & $\begin{array}{c}0.331 \\
(0.119)^{* * *}\end{array}$ \\
\hline$\%$ of fuel export & $\begin{array}{c}0.152 \\
(0.070)^{* *}\end{array}$ & $\begin{array}{c}1.865 \\
(0.329)^{* * *}\end{array}$ & & $\begin{array}{c}0.674 \\
(0.189)^{* * *}\end{array}$ \\
\hline$\%$ of commodity exports & & $\begin{array}{c}-1.809 \\
(0.474)^{* * *}\end{array}$ & & $\begin{array}{c}-0.468 \\
(0.171)^{* * *}\end{array}$ \\
\hline Ratio of Goods to Service exports & & $\begin{array}{c}-0.122 \\
(0.043)^{* * *}\end{array}$ & & \\
\hline $\begin{array}{l}\# \text { of Currency crisis } \\
(\mathrm{t}-5 \mid \mathrm{t}-1)\end{array}$ & & & & $\begin{array}{c}-0.031 \\
(0.012)^{* *}\end{array}$ \\
\hline \# of Banking crisis & $\begin{array}{c}-0.015 \\
(0.004)^{* * *}\end{array}$ & $\begin{array}{c}0.071 \\
(0.010)^{* * *}\end{array}$ & $\begin{array}{c}0.028 \\
(0.007)^{* * *}\end{array}$ & $\begin{array}{c}0.015 \\
(0.003)^{* * *}\end{array}$ \\
\hline Constant & $\begin{array}{l}-0.208 \\
(0.107)^{*}\end{array}$ & $\begin{array}{c}1.760 \\
(0.469)^{* * *}\end{array}$ & $\begin{array}{c}0.224 \\
(0.119)^{*}\end{array}$ & $\begin{array}{c}-0.577 \\
(0.180)^{* * *}\end{array}$ \\
\hline$N$ & 159 & 64 & 58 & 281 \\
\hline \# of countries & 22 & 22 & 20 & 22 \\
\hline Between R2 & 0.00 & 0.09 & 0.01 & 0.02 \\
\hline Within R2 & 0.58 & 0.83 & 0.84 & 0.53 \\
\hline Overall R2 & 0.01 & 0.08 & 0.01 & 0.00 \\
\hline
\end{tabular}

Notes: ${ }^{*} p<0.1 ; * * p<0.05 ; * * * p<0.01$. Estimated with country fixed effects. All the explanatory variables, except for reserve volatility and currency and banking crises, are lagged by one year to avoid endogeneity. 
Table 4: Over-Hoarding Estimates: 2010-2012

\begin{tabular}{ccccc|cccc}
\hline & \multicolumn{3}{c}{ Models (Pred. errors w/out FE) } & \multicolumn{5}{c}{ Models (Pred. errors w/ FE) } \\
& $1999-2006$ & $2007-09$ & $2010-2012$ & $1999-2012$ & $1999-2006$ & $2007-09$ & $2010-2012$ & $1999-2012$ \\
\hline Emerging Asia & -0.225 & 0.618 & 0.087 & -0.131 & -0.014 & 0.165 & 0.002 & 0.009 \\
Western Europe & 0.079 & -0.071 & 0.411 & -0.008 & 0.065 & -0.033 & 0.000 & 0.008 \\
E. \& C. Europe & -0.041 & -0.079 & 0.246 & 0.085 & -0.003 & 0.001 & 0.002 & 0.001 \\
Emerging Latin America & 0.036 & -0.129 & -0.275 & -0.042 & -0.011 & -0.004 & -0.001 & -0.014 \\
"Fragile Five" & -0.196 & 0.098 & -0.185 & -0.124 & -0.051 & 0.031 & 0.001 & -0.008 \\
BRICs & -0.143 & 0.131 & -0.100 & -0.095 & -0.012 & 0.017 & 0.001 & 0.006 \\
\hline Argentina & 0.067 & -0.254 & -0.232 & -0.025 & -0.006 & -0.032 & 0.000 & -0.010 \\
Brazil & 0.046 & -0.118 & -0.277 & -0.014 & 0.030 & -0.016 & 0.000 & 0.019 \\
Mexico & 0.053 & 0.011 & -0.308 & -0.012 & 0.029 & 0.040 & 0.000 & 0.012 \\
China & -0.265 & 0.742 & -0.097 & -0.139 & 0.018 & 0.124 & 0.000 & 0.019 \\
India & -0.483 & 0.414 & -0.238 & -0.304 & -0.171 & & 0.006 & -0.035 \\
Indonesia & -0.473 & 0.495 & -0.331 & -0.260 & -0.116 & 0.073 & 0.000 & -0.021 \\
Korea & -0.412 & 0.699 & -0.161 & -0.254 & -0.137 & 0.123 & 0.000 & -0.049 \\
Malaysia & -0.253 & 0.603 & 0.014 & -0.125 & -0.082 & 0.100 & 0.000 & -0.043 \\
Thailand & -0.173 & 0.739 & 0.121 & -0.028 & 0.066 & 0.156 & 0.000 & 0.080 \\
South Africa & 0.019 & -0.192 & -0.209 & -0.095 & 0.028 & -0.004 & 0.000 & 0.008 \\
Turkey & -0.089 & -0.003 & 0.121 & 0.052 & -0.029 & 0.070 & 0.000 & -0.012 \\
\hline & & & & & & & \\
\hline
\end{tabular}


Table 5: The Proxy of Over-hoarding and Exchange Rate Depreciation in 2012-13

\begin{tabular}{|c|c|c|c|c|c|c|c|c|}
\hline \multirow[b]{3}{*}{ Model } & \multicolumn{8}{|c|}{ Dep. Var.: \% of Depreciation 2012-13 } \\
\hline & \multicolumn{4}{|c|}{ Prediction errors 2010-12 } & \multicolumn{4}{|c|}{ Prediction errors as of 2012} \\
\hline & $\begin{array}{c}\text { 1999-2006 } \\
\text { (1) }\end{array}$ & $\begin{array}{c}2007-2009 \\
(2)\end{array}$ & $\begin{array}{c}2010-2012 \\
\text { (3) }\end{array}$ & $\begin{array}{c}1999-2012 \\
(4)\end{array}$ & $\begin{array}{c}1999-2006 \\
(5)\end{array}$ & $\begin{array}{c}2007-2009 \\
(6)\end{array}$ & $\begin{array}{c}2010-2012 \\
(7)\end{array}$ & $\begin{array}{c}1999-2012 \\
(8)\end{array}$ \\
\hline \multirow[t]{2}{*}{ Pred. errors. } & -0.065 & -0.055 & -0.018 & -0.101 & -0.055 & -0.077 & -0.061 & -0.114 \\
\hline & $(0.031)^{* *}$ & $(0.032)^{*}$ & $(0.016)$ & $(0.052)^{*}$ & $(0.030)^{*}$ & $(0.042)^{*}$ & $(0.035)^{*}$ & $(0.061)^{*}$ \\
\hline \multirow[t]{2}{*}{ Constant } & 0.021 & 0.031 & 0.016 & 0.019 & 0.027 & 0.038 & 0.018 & 0.026 \\
\hline & $(0.008)^{* *}$ & $(0.011)^{* * *}$ & $(0.009)^{*}$ & $(0.008)^{* *}$ & $(0.010)^{* * *}$ & $(0.013) * * *$ & $(0.010)^{*}$ & $(0.009) * * *$ \\
\hline Adjusted R2 & 0.03 & 0.06 & 0.00 & 0.05 & 0.01 & 0.11 & 0.06 & 0.07 \\
\hline$N$ & 75 & 59 & 68 & 78 & 59 & 49 & 52 & 63 \\
\hline
\end{tabular}

Notes: $* p<0.1 ; * * p<0.05 ; * * * p<0.01$. Standard errors are robust standard errors. 
Table 6: Comparison b/w OLS-FE and PCA Estimation Results - Developing Countries

\begin{tabular}{|c|c|c|c|c|c|c|c|c|c|c|c|}
\hline 1999-2006 & OLS-FE & PC & 2007-2009 & OLS-FE & PC & 2010-2012 & OLS-FE & PC & 1999-2012 & OLS-FE & PC \\
\hline Propensity to Import & + & & Propensity to Import & + & & Financial Exposure & - & & Propensity to Import & + & + \\
\hline M2 (\% of GDP) & + & $(+)$ & Reserve Volatility & + & & SWF & + & + & Reserve Volatility & - & + \\
\hline Net Portfolio Liab. & - & - & Opportunity Cost & + & & Bilateral swap & - & - & Fixed/Peg & - & - \\
\hline Gross saving & + & + & Net Debt Liab. & + & & Gross saving & + & + & M2 (\% of GDP) & + & \\
\hline Outward Direct Inv. & - & & Net FDI Liab. Pos. & - & + & Outward Direct Inv. & + & & Financial Exposure & + & + \\
\hline Joneses x Asia & + & + & Chinn-Ito & - & - & Joneses $\mathrm{x}$ Europe & - & - & SWF & - & - \\
\hline Joneses x Europe & + & + & Gross saving & + & + & Joneses x MENA & + & + & Macro Prudential & + & + \\
\hline$\%$ of fuel export & + & + & Joneses x Asia & - & - & \# of Banking crisis & - & - & Gross saving & + & + \\
\hline \multirow[t]{3}{*}{ Commodity Volatility } & + & & Commodity exports & + & & & & & Joneses x Asia & + & + \\
\hline & & & \# of Currency crisis & + & & & & & Joneses $\mathrm{x}$ Europe & - & \\
\hline & & & & & & & & & $\%$ of fuel export & + & + \\
\hline$N$ & 441 & & $N$ & 182 & & $N$ & 154 & & $N$ & 777 & \\
\hline \# of countries & 70 & & \# of countries & 67 & & \# of countries & 58 & & \# of countries & 73 & \\
\hline $\mathrm{B} / \mathrm{w} \mathrm{R} 2$ & 0.21 & 0.05 & $\mathrm{~B} / \mathrm{w}$ R2 & 0.01 & 0.12 & $\mathrm{~B} / \mathrm{w} \mathrm{R} 2$ & 0.01 & 0.05 & $\mathrm{~B} / \mathrm{w} \mathrm{R} 2$ & 0.48 & 0.25 \\
\hline $\mathrm{W} /$ in $\mathrm{R} 2$ & 0.27 & 0.20 & $\mathrm{~W} /$ in $\mathrm{R} 2$ & 0.35 & 0.16 & $\mathrm{~W} /$ in $\mathrm{R} 2$ & 0.47 & 0.39 & $\mathrm{~W} /$ in $\mathrm{R} 2$ & 0.35 & 0.29 \\
\hline Overall R2 & 0.31 & 0.12 & Overall R2 & 0.01 & 0.12 & Overall R2 & 0.01 & 0.06 & Overall R2 & 0.54 & 0.37 \\
\hline
\end{tabular}

Other estimates found associated by PCA:

Crawling Peg (-); fixed/Peg (-); net FDI Liab.(+); currency crisis (-); banking crisis $(+/-)$; Chinn-Ito (-); manufacturing exp. (-); (Opp. Cost $(+))$

\section{Other estimates found associated by PCA:} Swap (+);
Other estimates found associated by PCA:

Chinn-Ito (-); net FDI Liab.(+); Reserve vol. $(-)$

Note: The signs in parentheses in the "PCA" columns indicate they are based on the results of the estimations where the variables that are not highly correlated with any of the PCs are included in the estimation (that is, models shown in column (2) of each table). 
Table 7: Estimation Results of BMA - Developing Countries

\begin{tabular}{|c|c|c|c|c|c|c|c|c|c|c|c|}
\hline $\begin{array}{c}1999-2006 \\
(N=441)\end{array}$ & Coeff. & PIP & $\begin{array}{c}2007-2009 \\
(N=182)\end{array}$ & Coeff. & PIP & $\begin{array}{c}2010-2012 \\
(N=154)\end{array}$ & Coeff. & PIP & $\begin{array}{c}1999-2012 \\
(N=777)\end{array}$ & Coeff. & PIP \\
\hline Propensity to Import (+) & 0.168 & 1.00 & Propensity to Import (+) & 0.239 & 1.00 & Financial Exposure (-) & 0.054 & 1.00 & Propensity to Import (+) & 0.159 & 1.00 \\
\hline M2 (\% of GDP) $(+)$ & 0.140 & 1.00 & Reserve Volatility $(+)$ & -0.204 & 1.00 & SWF (+) & 0.008 & 1.00 & Reserve Volatility (-) & -0.039 & 1.00 \\
\hline Net Portfolio Liab. (-) & 0.078 & 1.00 & Opportunity Cost $(+)$ & 0.024 & 1.00 & Bilateral swap (-) & -0.050 & 1.00 & Fixed/Peg (-) & -0.018 & 1.00 \\
\hline Gross saving $(+)$ & 0.127 & 1.00 & Net Debt Liab. (+) & -0.080 & 1.00 & Gross saving $(+)$ & 0.670 & 1.00 & M2 (\% of GDP) (+) & 0.152 & 1.00 \\
\hline Outward Direct Inv. (-) & -0.586 & 1.00 & Net FDI Liab. Pos. (-) & -0.056 & 1.00 & Outward Direct Inv. (+) & -0.639 & 1.00 & Financial Exposure (+) & 0.032 & 1.00 \\
\hline Joneses x Asia (+) & -0.011 & 1.00 & Chinn-Ito (-) & -0.060 & 1.00 & Joneses x Europe (-) & -0.548 & 1.00 & SWF (-) & 0.028 & 1.00 \\
\hline Joneses x Europe (+) & 0.167 & 1.00 & Gross saving $(+)$ & 0.475 & 1.00 & Joneses x MENA $(+)$ & 0.189 & 1.00 & Macro Prudential (+) & 0.037 & 1.00 \\
\hline$\%$ of fuel export $(+)$ & 0.083 & 1.00 & Joneses x Asia (-) & -0.369 & 1.00 & \# of Banking crisis (-) & 0.000 & 1.00 & Gross saving $(+)$ & 0.312 & 1.00 \\
\hline Commodity Volatility (+) & -0.075 & 1.00 & Commodity exports (+) & 0.027 & 1.00 & Net Debt Liab. & $\begin{array}{l}-0.136 \\
\end{array}$ & 0.92 & Joneses x Asia (+) & -0.121 & 1.00 \\
\hline Financial Exposure & 0.030 & 1.00 & \# of Currency crisis (+) & -0.042 & 1.00 & M2 (\% of GDP) & 0.157 & 0.91 & Joneses x Europe (-) & -0.016 & 1.00 \\
\hline Net Debt Liab. & -0.070 & 1.00 & M2 (\% of GDP) & 0.196 & 1.00 & Fixed/Peg & -0.062 & 0.70 & $\%$ of fuel export $(+)$ & 0.103 & 1.00 \\
\hline Reserve Volatility & -0.031 & 0.99 & $\%$ of fuel export & 0.199 & 0.94 & $\%$ of Manuf. Exp. & -0.063 & 0.38 & Joneses MENA & 0.300 & 1.00 \\
\hline Crawl Peg & 0.030 & 0.99 & Fixed/Peg & -0.083 & 0.93 & Reserve Volatility & -0.096 & 0.35 & Outward Dir. Inv. & -0.703 & 1.00 \\
\hline Joneses MENA & 0.290 & 0.97 & Financial Exposure & 0.022 & 0.81 & $\%$ of fuel export & 0.036 & 0.29 & Net Debt Liab. & -0.077 & 1.00 \\
\hline Macro Prudential & 0.029 & 0.81 & Outward Dir. Inv. & -0.897 & 0.73 & \# of Currency crisis & 0.018 & 0.28 & Crawl Peg & 0.036 & 0.97 \\
\hline Net FDI Liab. & 0.046 & 0.81 & Joneses $\mathrm{x}$ Europe & -0.453 & 0.55 & Chinn-Ito & -0.019 & 0.25 & Chinn-Ito & -0.037 & 0.89 \\
\hline SWF & 0.016 & 0.48 & \# of Banking Crisis & -0.340 & 0.45 & Joneses $\mathrm{x}$ Asia & -0.250 & 0.18 & Joneses SSA & 0.061 & 0.31 \\
\hline Joneses SSA & 0.022 & 0.22 & Joneses West Hem. & 0.025 & 0.45 & Joneses West Hem. & -0.455 & 0.17 & Joneses West Hem. & -0.061 & 0.29 \\
\hline Joneses West Hem. & -0.045 & 0.21 & Joneses MENA & 0.041 & 0.35 & Joneses SSA & -0.425 & 0.17 & Bilateral swap & -0.007 & 0.23 \\
\hline \# of Currency crisis & -0.001 & 0.16 & Joneses SSA & -0.069 & 0.18 & $\%$ of Commd. Exp. & -0.001 & 0.17 & $\%$ of Manuf. Exp. & -0.001 & 0.06 \\
\hline Chinn-Ito & -0.001 & 0.08 & Bilateral swap & -0.007 & 0.13 & Crawl Peg & 0.006 & 0.14 & \# of Currency Crisis & 0.000 & 0.06 \\
\hline$\%$ of Manuf. Exp. & 0.001 & 0.06 & Goods/Serv. Exp. Ratios & 0.002 & 0.12 & Net Portfolio Liab. & -0.018 & 0.1 & $\%$ of Commd. Exp. & -0.002 & 0.05 \\
\hline Fixed/Peg & 0.000 & 0.06 & Crawl Peg & 0.003 & 0.10 & Commodity Volatility & 0.016 & 0.08 & Commodity Volatility & 0.001 & 0.05 \\
\hline$\%$ of Commd. Exp. & -0.001 & 0.06 & Net Portfolio Liab. & -0.005 & 0.08 & Goods/Serv. Exp. Ratios & 0.001 & 0.08 & Net Portfolio Liab. & 0.001 & 0.04 \\
\hline Swap & 0.001 & 0.05 & Macro Prudential & 0.001 & 0.07 & Net FDI Liab. & 0.004 & 0.08 & Goods/Serv. Exp. Ratios & 0.000 & 0.04 \\
\hline Goods/Serv. Exp. Ratios & 0.000 & 0.05 & Commodity Volatility & 0.006 & 0.07 & Macro Prudential & 0.002 & 0.07 & Opp. Cost & 0.000 & 0.04 \\
\hline Opp. Cost & -0.000 & 0.05 & SWF & 0.000 & & Propensity to Import & -0.002 & 0.06 & Net FDI Liab. & 0.000 & 0.04 \\
\hline \# of Banking Crisis & 0.000 & 0.05 & $\%$ of Manuf. Ex & 0.007 & 0.06 & & 0.000 & 0.05 & \# of Banking Crisis & 0.000 & 0.04 \\
\hline
\end{tabular}

Notes: "PIP" refers to posterior inclusion probability, that is, the posterior probability that a variable is to be included in the model. The PIP of 0.5 approximately corresponds to a $t$ ratio of one in absolute value. Figures in bold are the estimates whose PIP's are 0.50 or greater. The explanatory variables shown above the horizontal line are the "focus regressors" and those below are "auxiliary regressors." 
Figure 1: International Reserve Holding as a ratio to GDP (a) and to the world total (b)

(a) IR Holding as \% of GDP

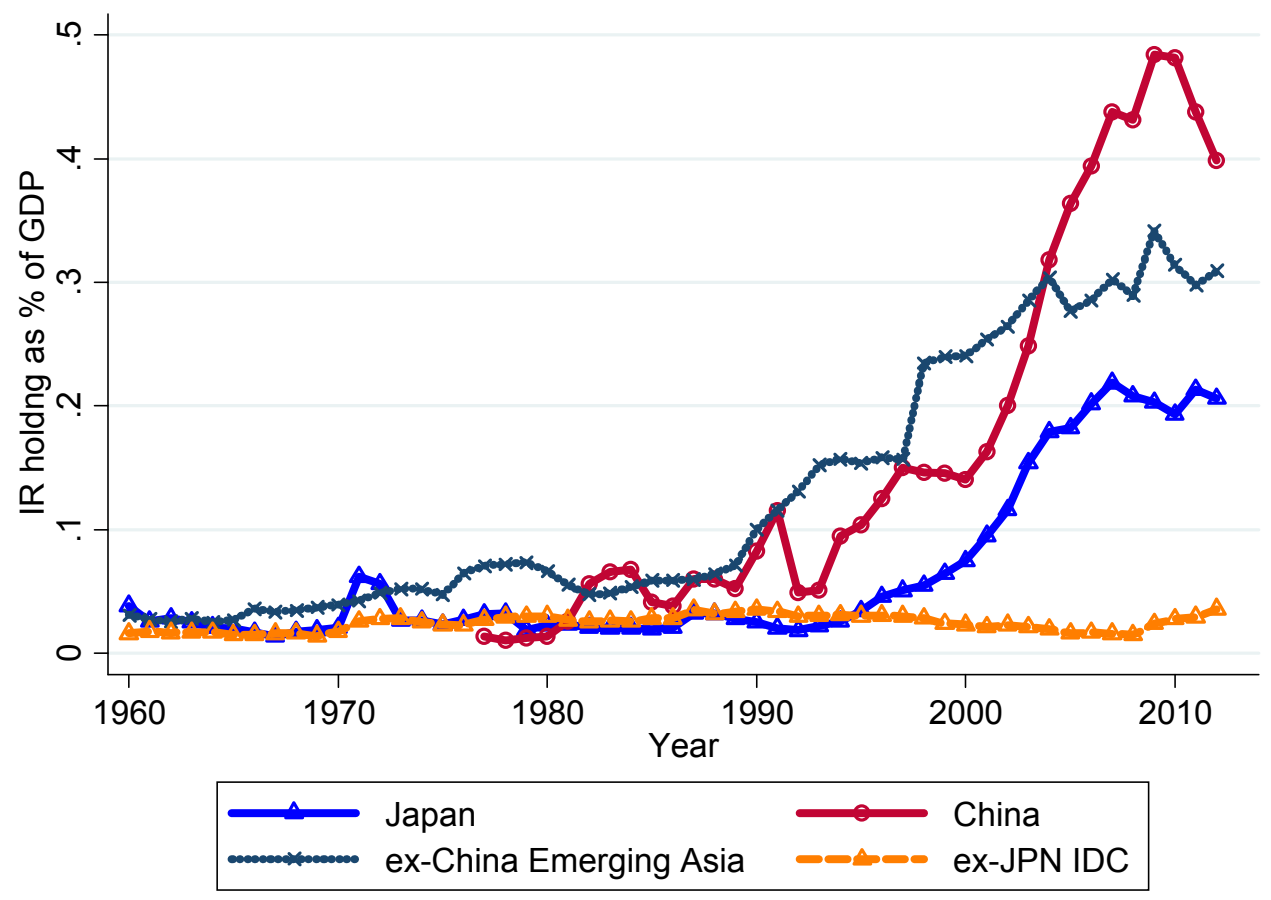

Note: For the country groups, the group's aggregate IR is divided by the group's aggregated GDP

(b) IR Holding as \% of the World's IR Total

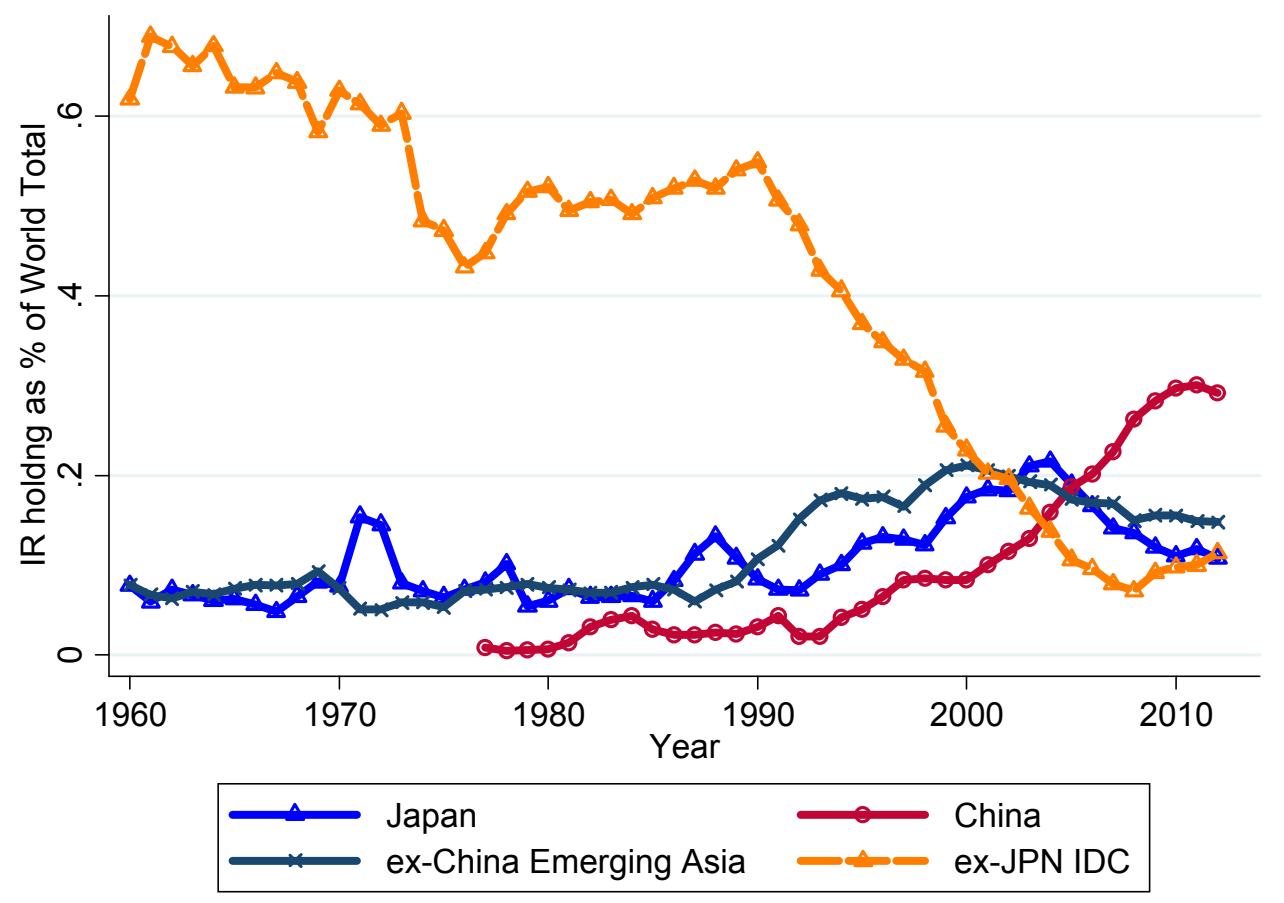

Note: For the country groups, the group's aggregate IR is divided the world's total IR 
Figure 2: Predictions with Different Estimation Models
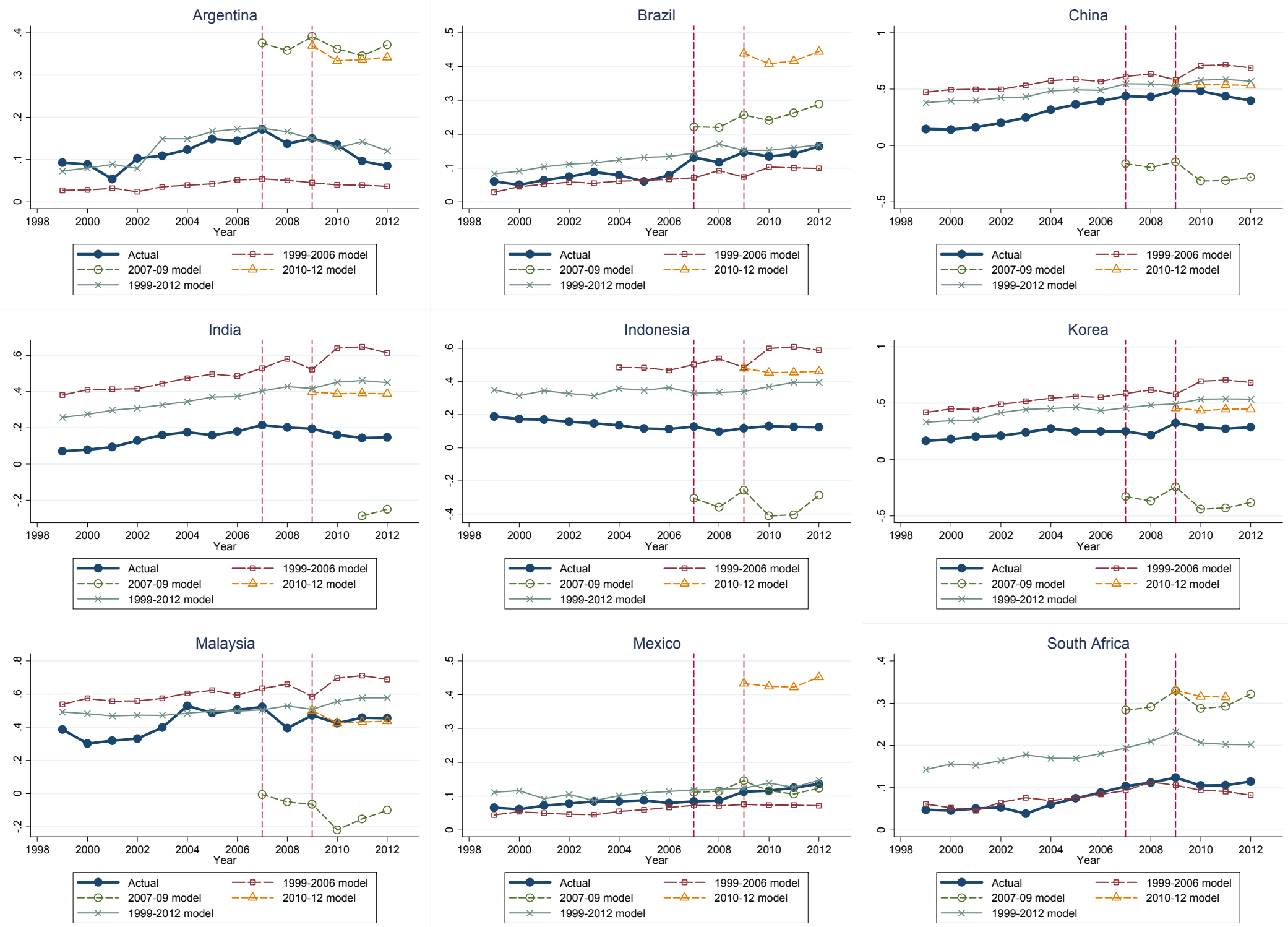
Figure 2-cont: Predictions with Different Estimation Models
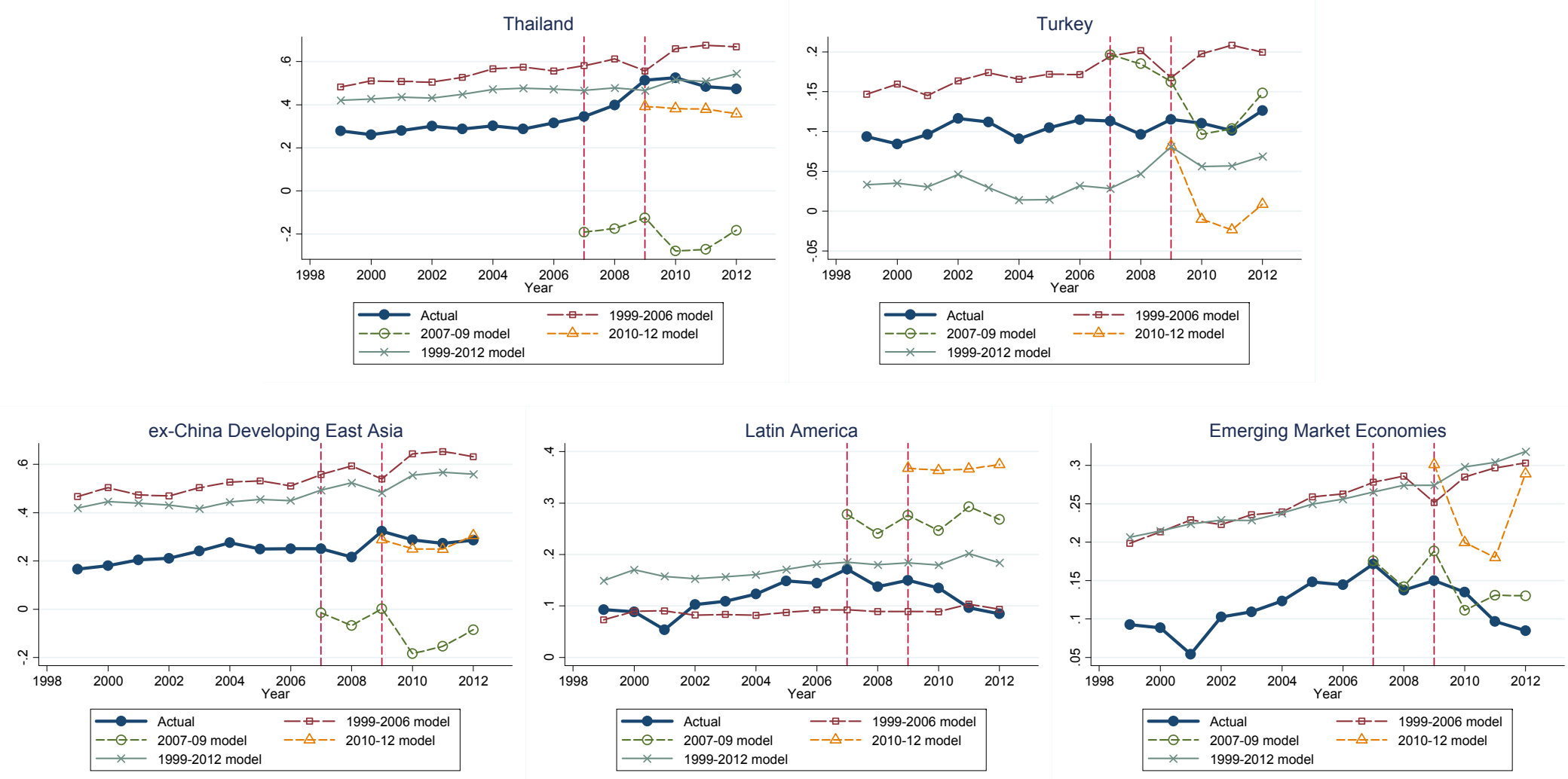


\section{Figure 3: Actual vs. Predicted Levels of IR Holding}

(a) Predictions based on the 1999-2006 model

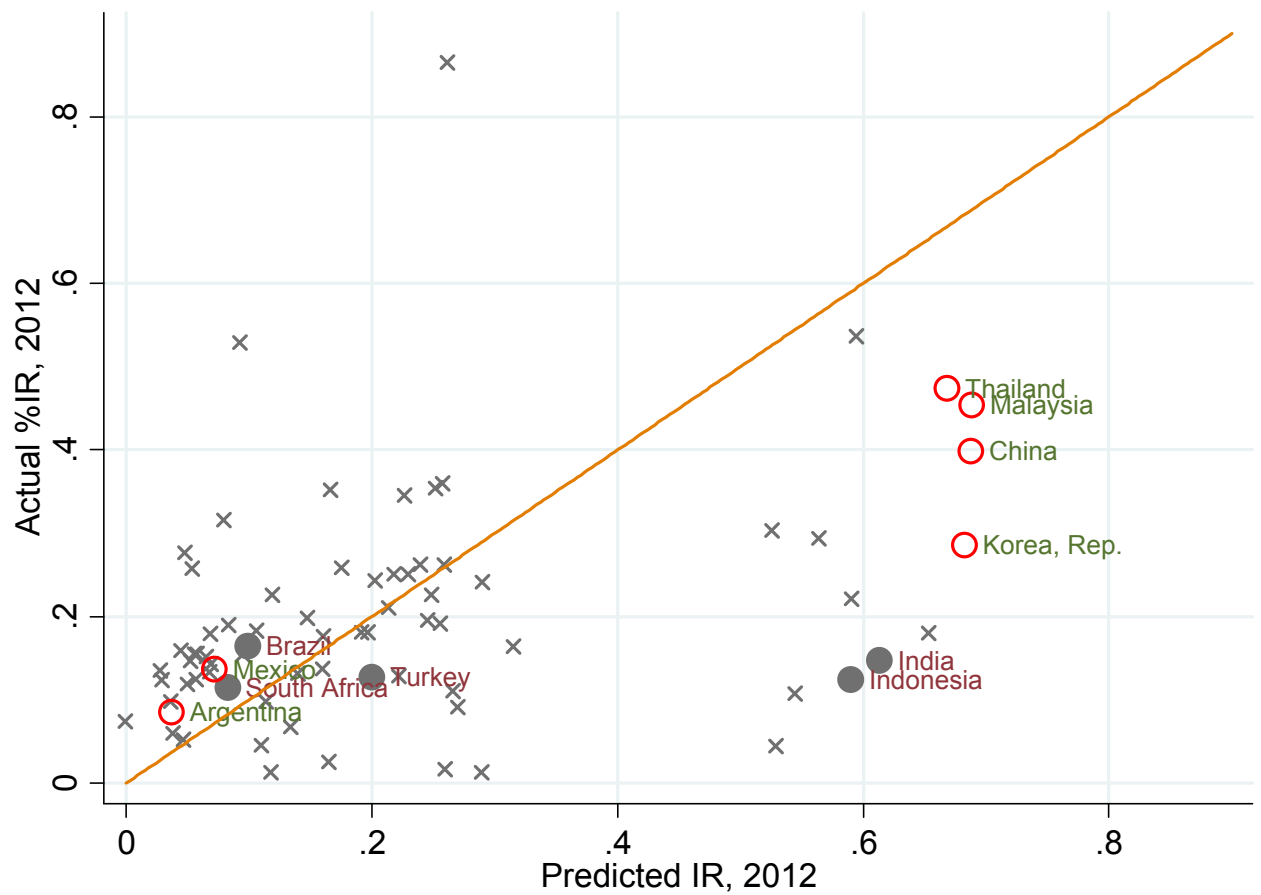

(b) Predictions based on the 1999-2012 model

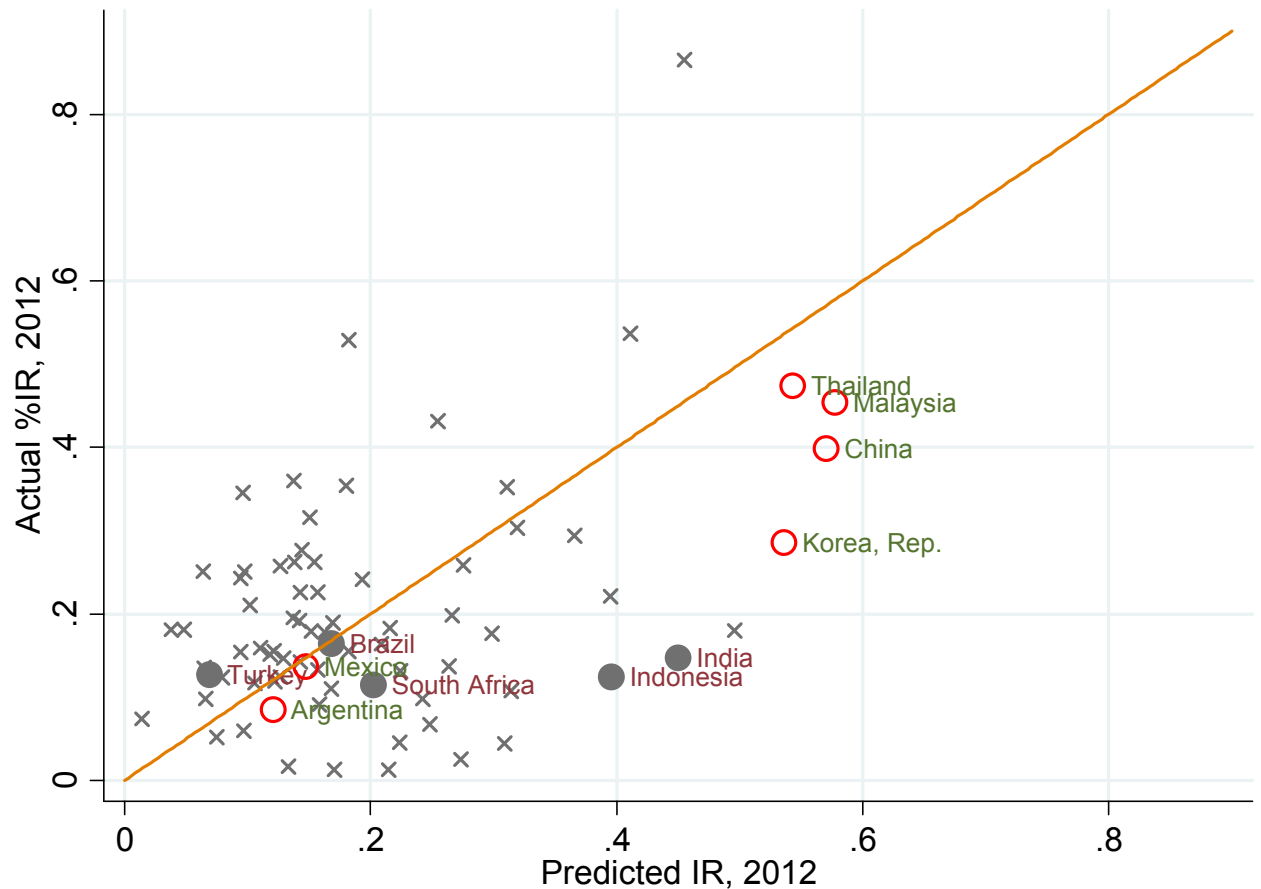

Note: For clarity purposes, the observations with actual or predicted IR levels greater than $80 \%$ (of GDP) are omitted from presentation. 
Figure 4: Over-hoarding and Exchange Rate Depreciation
(a) 1999-2006 model
(b) 2007-09 model
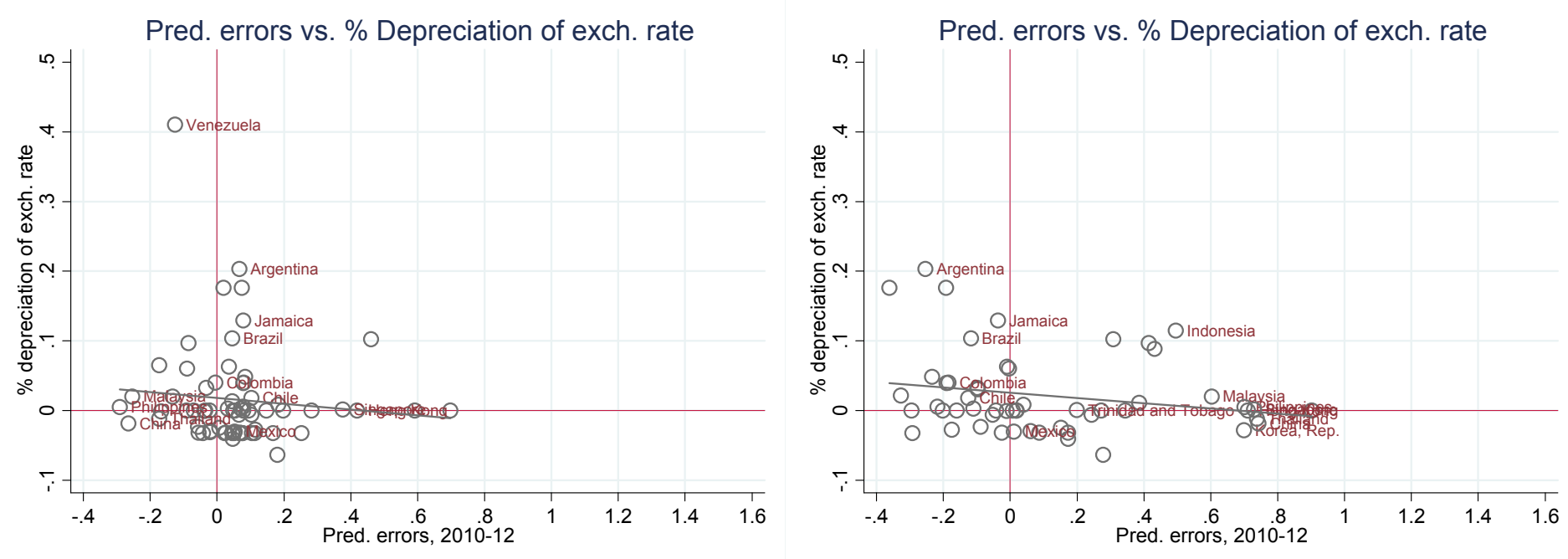

(c) 2010-12 model

(d) 1999-2012 model
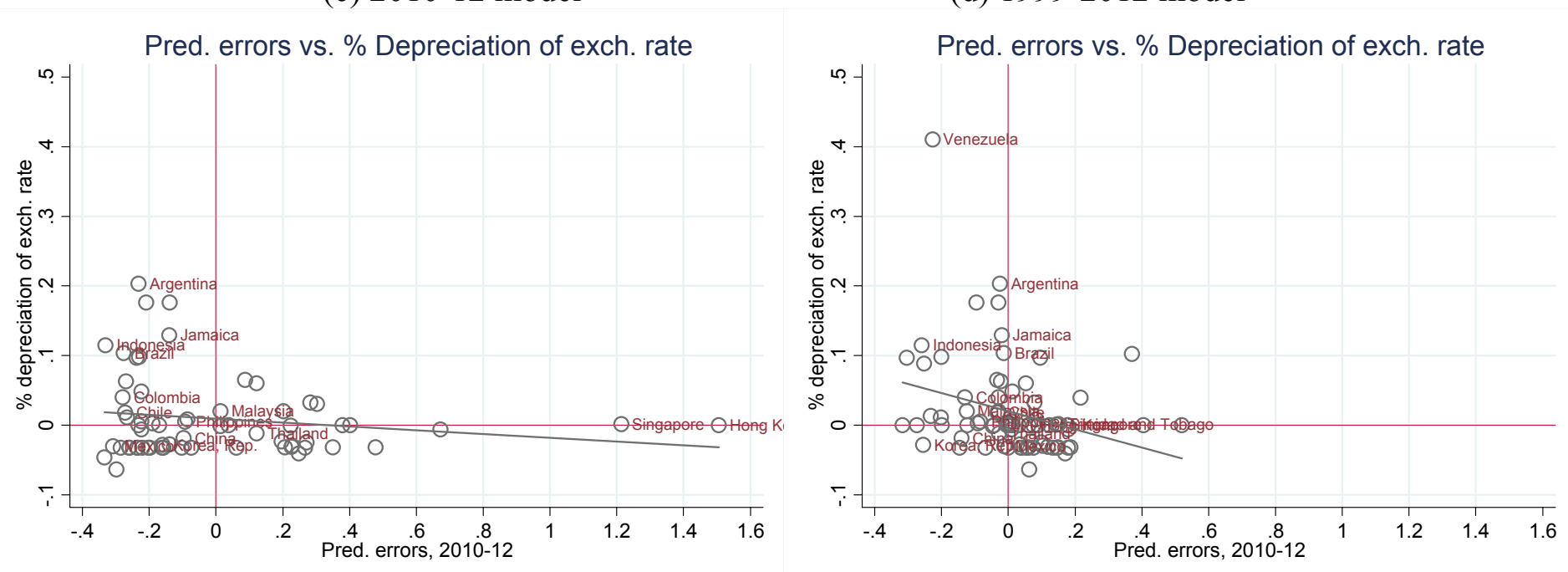